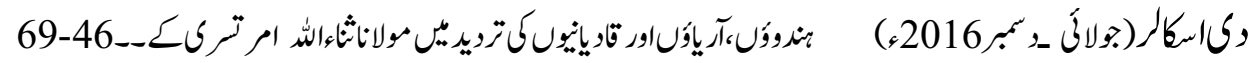

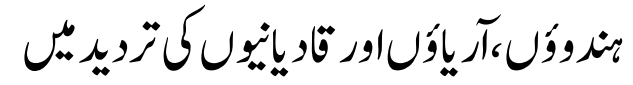

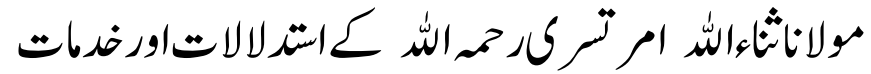

\title{
LOGICAL ARGUMENTS AND SERVICES OF MAULANA SANAULLAH AMRISRI IN REFUTING ARYA, HINDU, AND QADYANI VIEWS
}

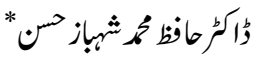

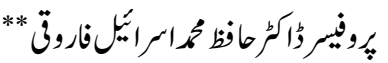

DOI: 10.29370/siarj/issue3ar4

Link: https://doi.org/10.29370/siarj/issue3ar4

\begin{abstract}
:
The Sub-continent was under the occupation of the British during seventeenth century to twentieth century. The British were Christians by religion, they started a systematic policy of capitalizing on the decadence of the Muslims, and they started efforts to deviate them from the real essence of Islam. The Christians deliberately planted Arya, Hindu, Natury, and Qadianis so that no Muslim should; resort to Islam, flare up upon the desecration of the Holy Quran and Sunnah, demand death sentence for any blasphemer, shout at encroachment upon his chastity and differentiate between what is sanctioned or forbidden in Islam. The services of Maulana Sana Ullah Amratsari regarding comparison of religions are valuable and unprecedented. Maulana was a great Islamic Scholar, a great defender of Islam. Maulana Sana Ullah is the writer of four Tafseers of the Holy Quran and has authored a number of valuable books on comparative religions with special focus on superiority of Islam as compared to other religions i.e., Judaism, Christianity, Hinduism, Arya and Qadianiat etc. Whenever anybody used to write, speak or criticize the teaching of Islam, the Holy Quran and the Holy Prophet, Maulana Sana Ullah replied the objections raised by non Muslims. Many religious scholars had been included amongst the listeners of Maulana. That is why the Arians, Christians and Qadianies always thought Maulana as their real opponent.
\end{abstract}

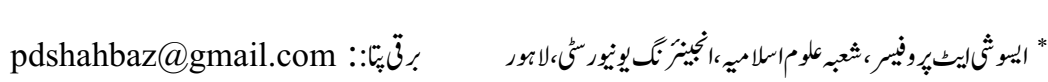

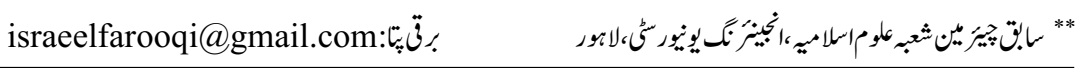




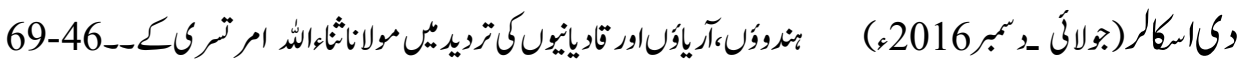

KEYWORDS: Arya, Hindu, Qadianis, Maulana Sana Ullah Amratsari, Arguments and Services.

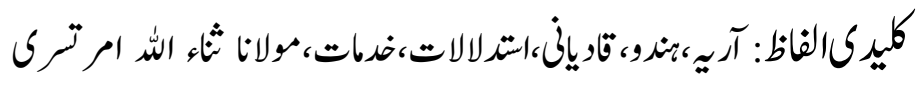

تحارف:

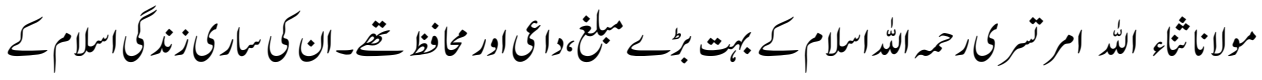

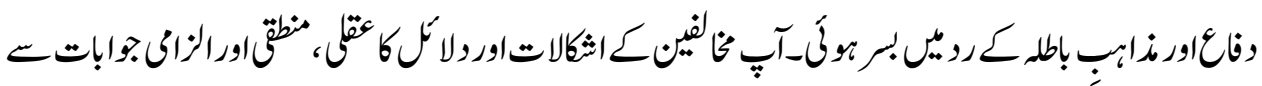

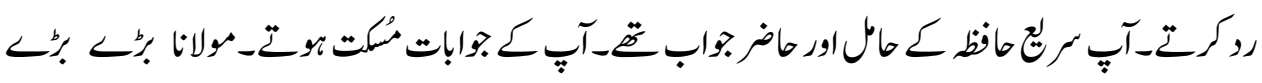

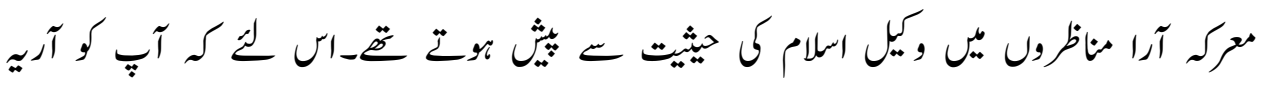

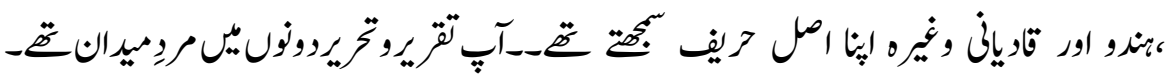

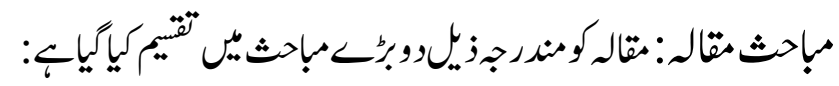

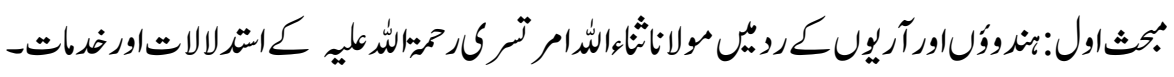

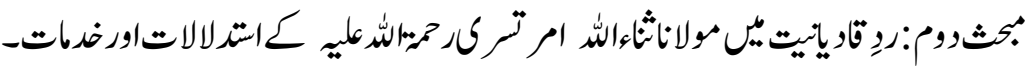

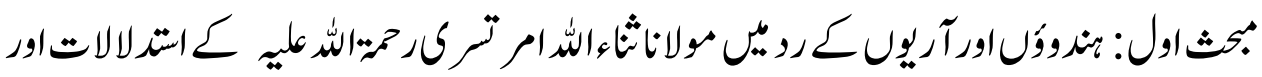

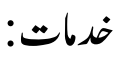

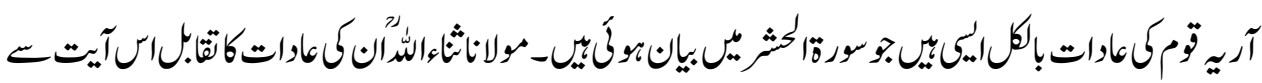

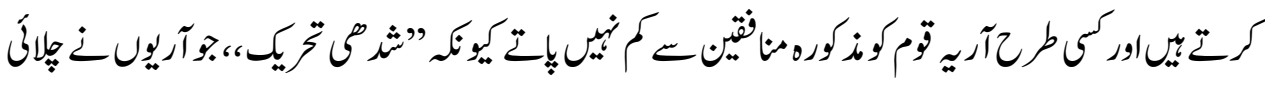

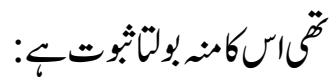

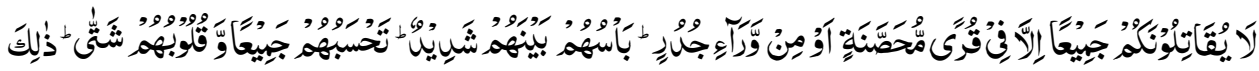

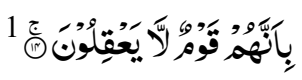

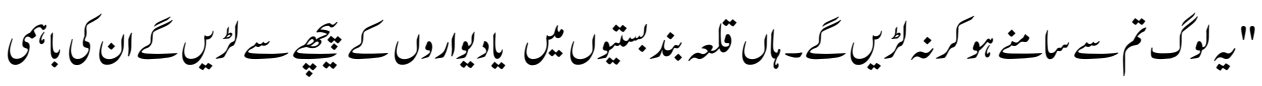

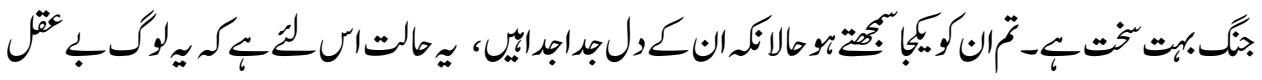
"

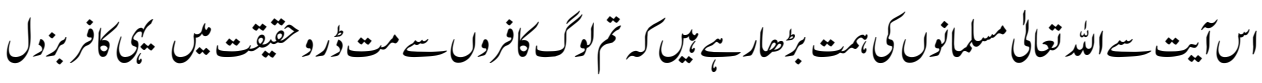




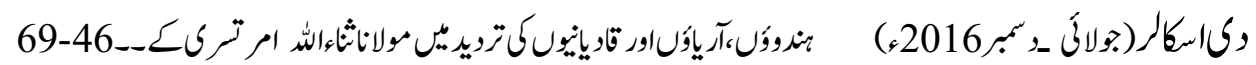

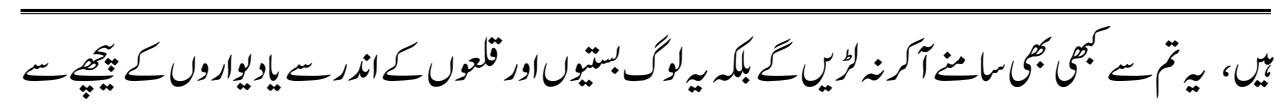

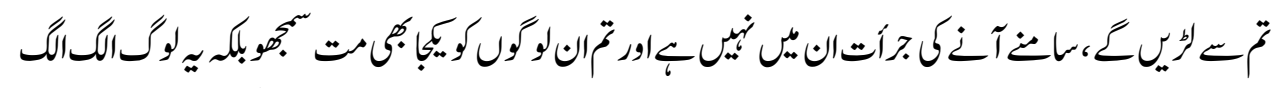

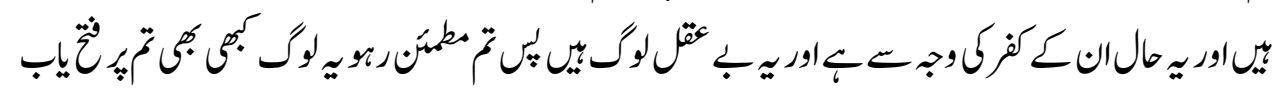
"ris

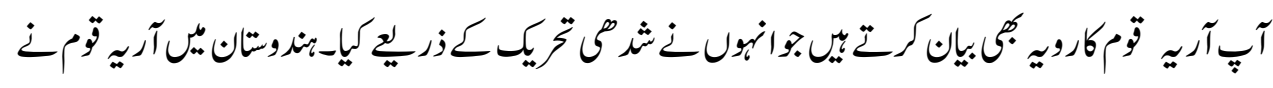

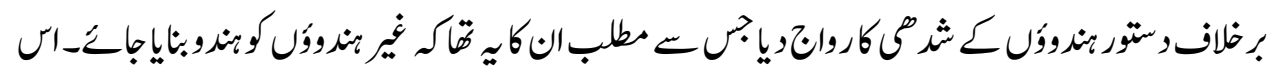

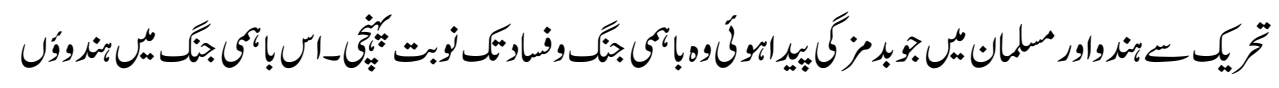

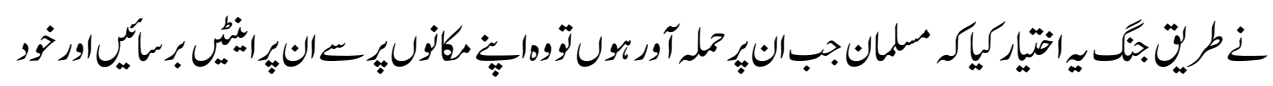

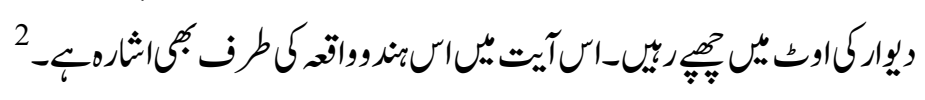

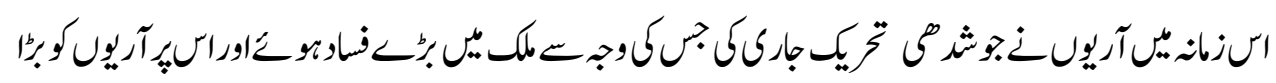

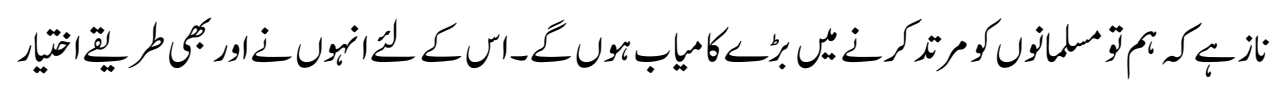
$-2$

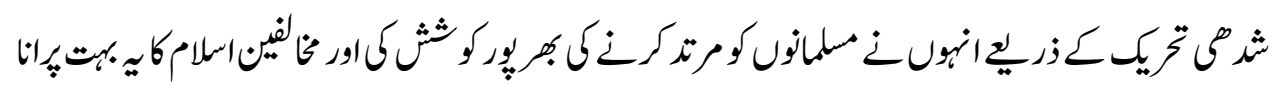

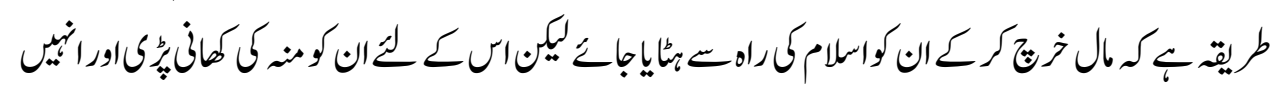

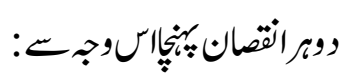

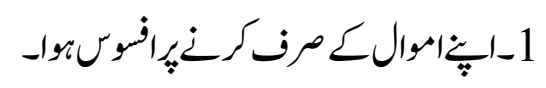

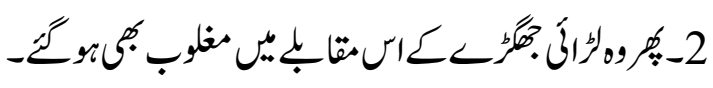

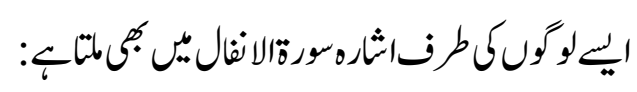

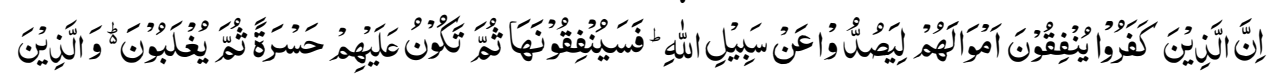
3

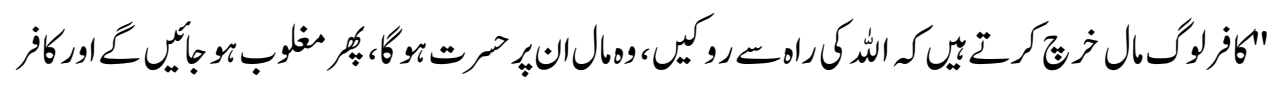

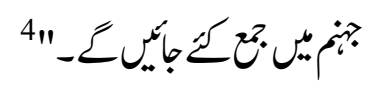

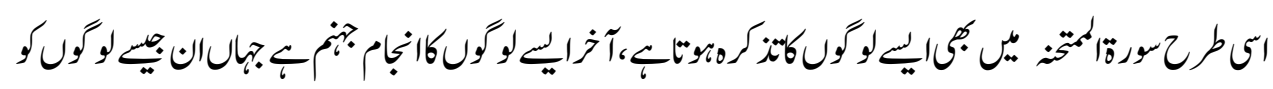

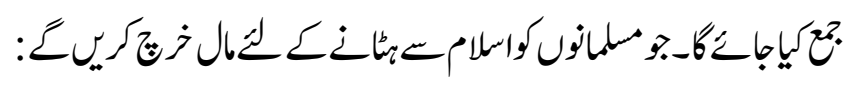




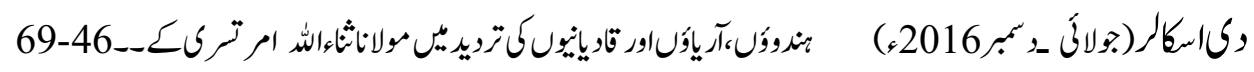

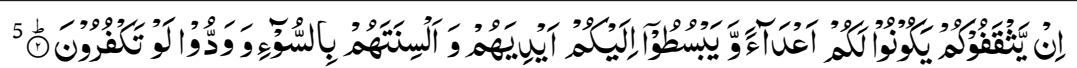

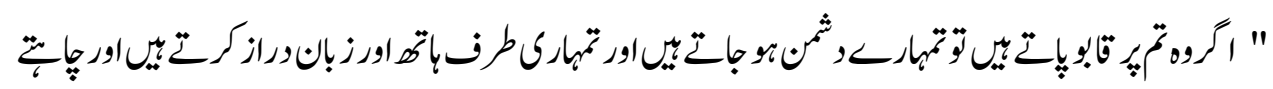

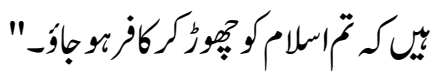

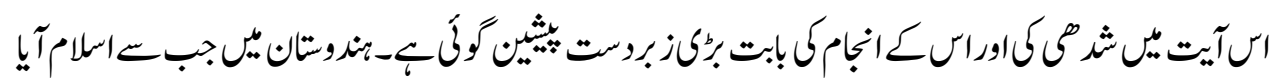

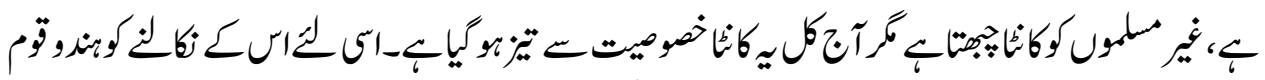

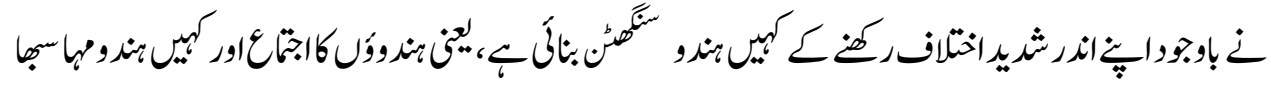

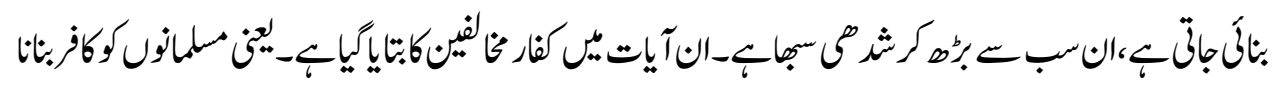

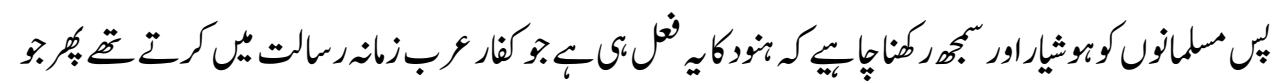

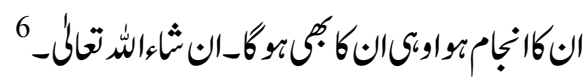

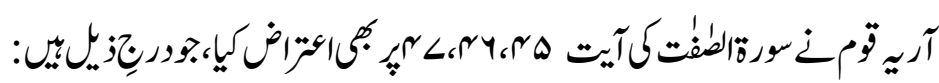

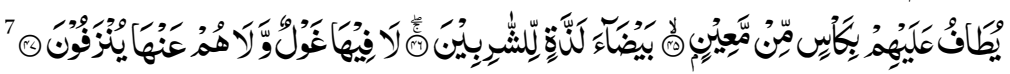

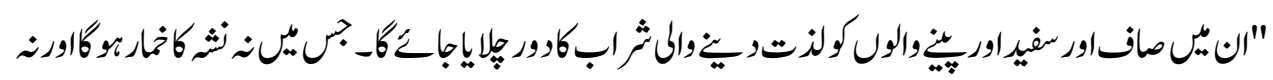

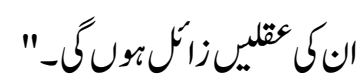

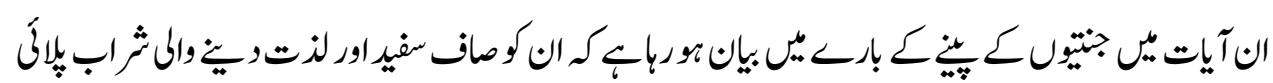
جإن

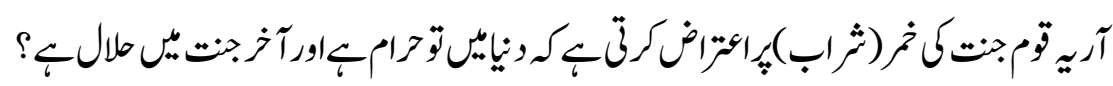

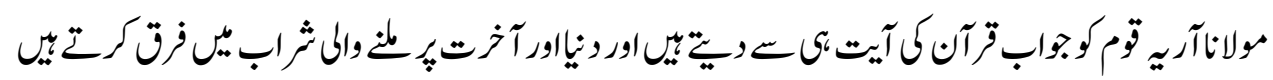

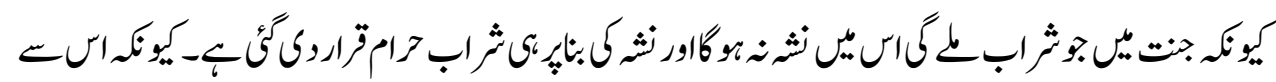

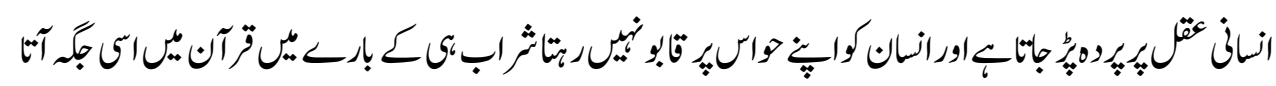

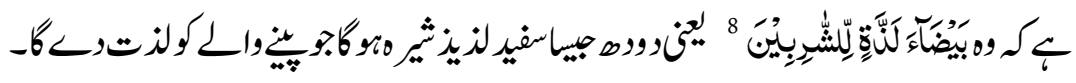

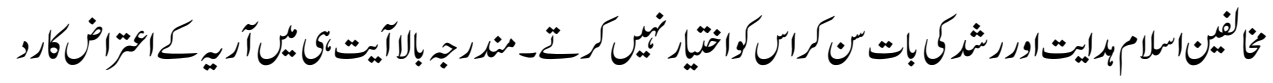

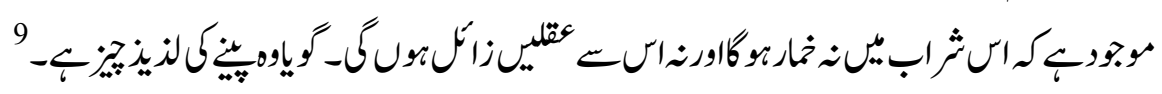

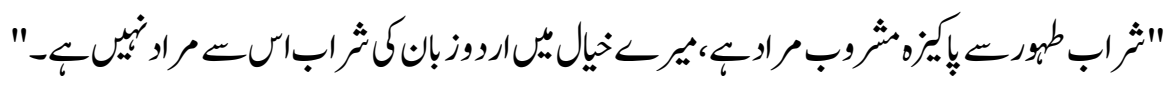

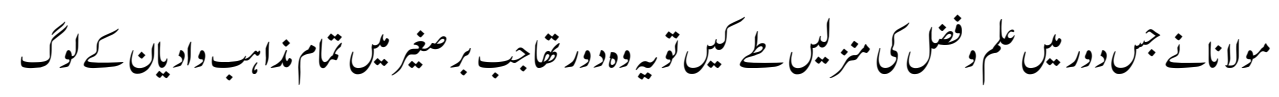




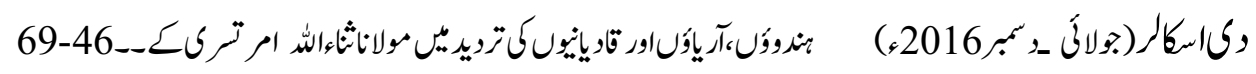

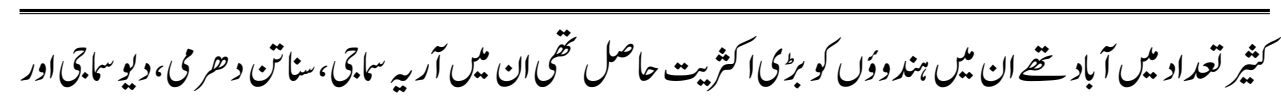

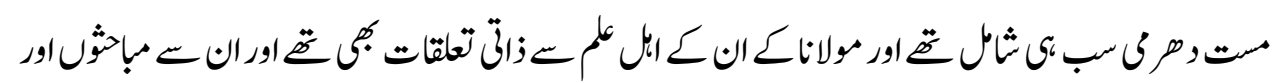

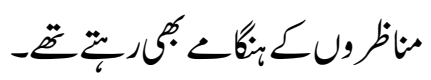

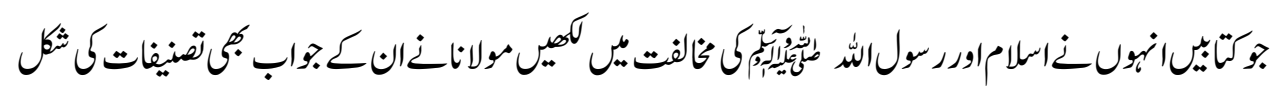

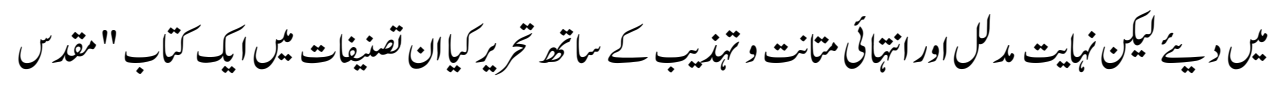

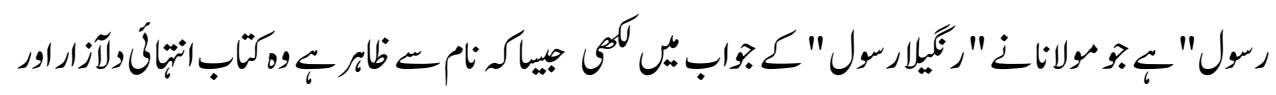

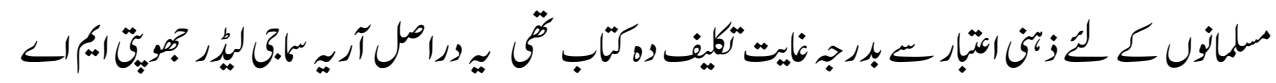

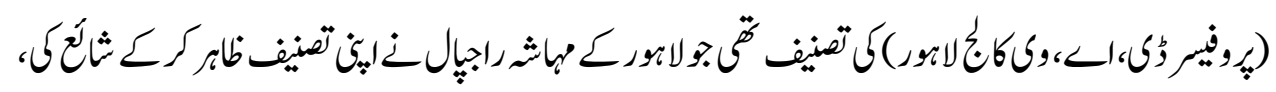

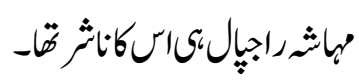

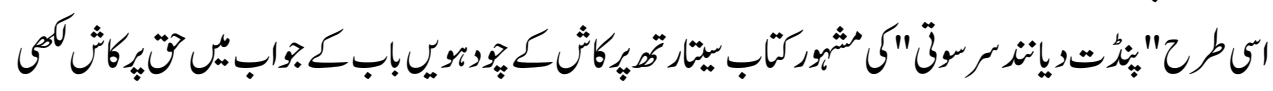

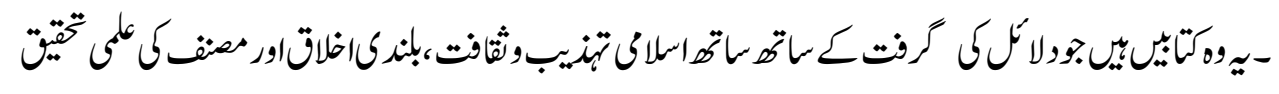

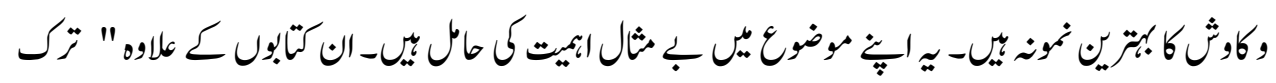

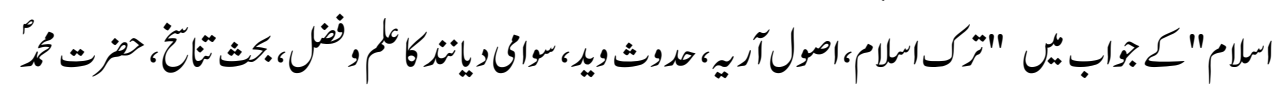

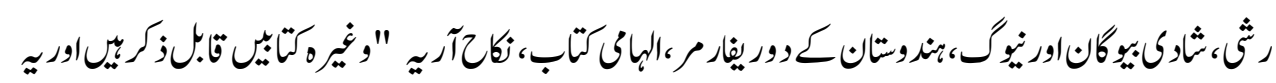

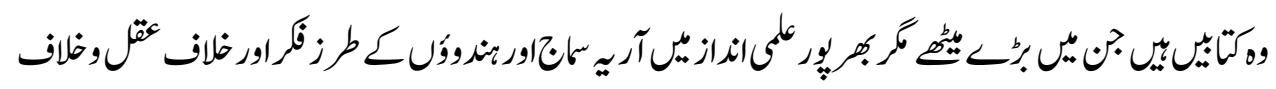

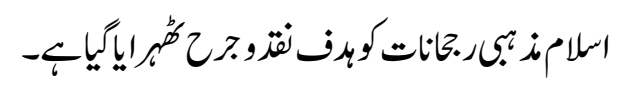

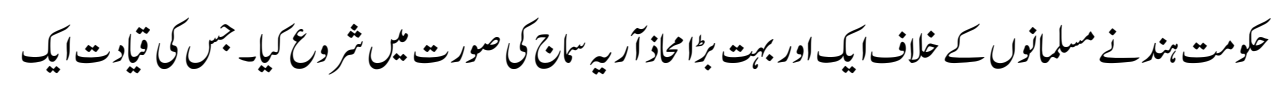

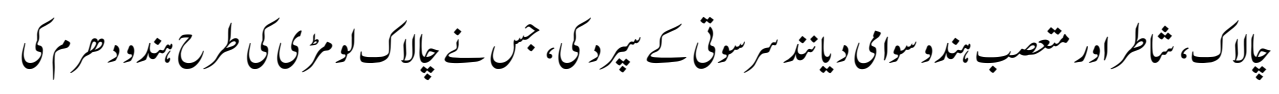

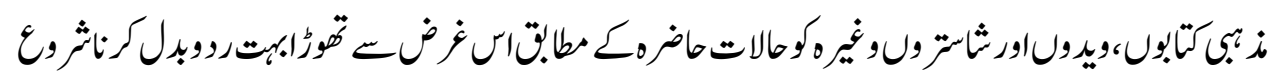

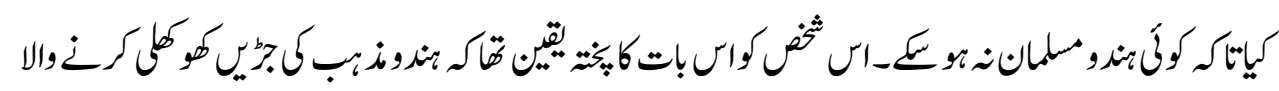

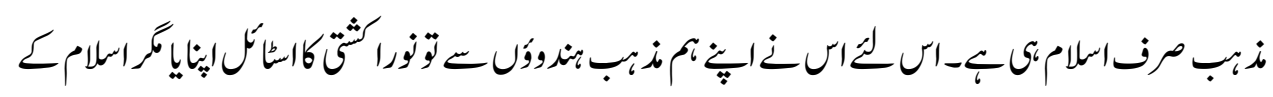

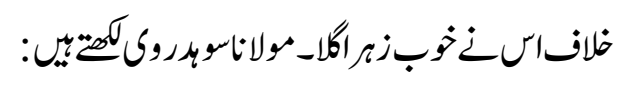

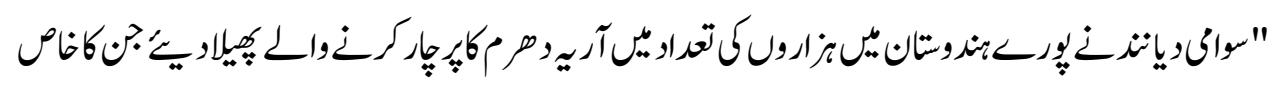

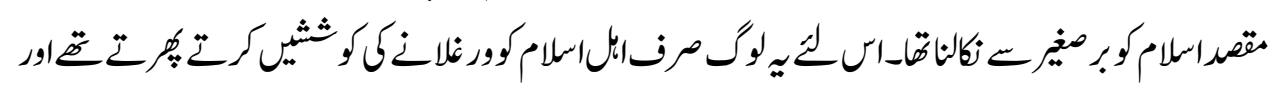




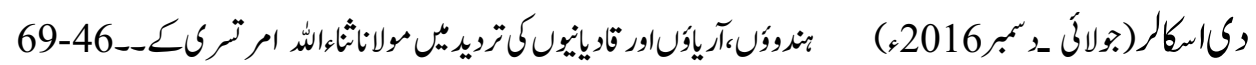

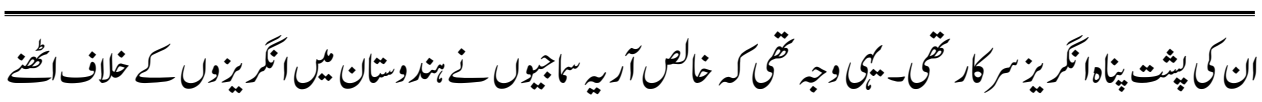

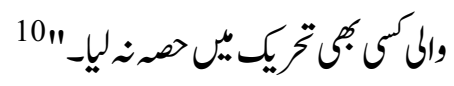

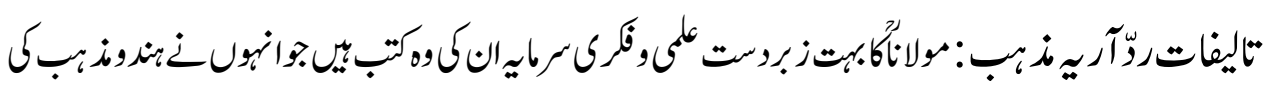

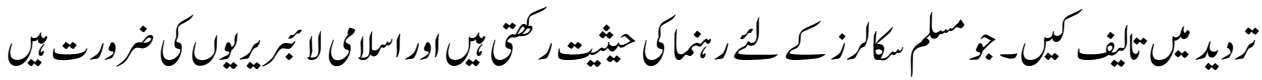

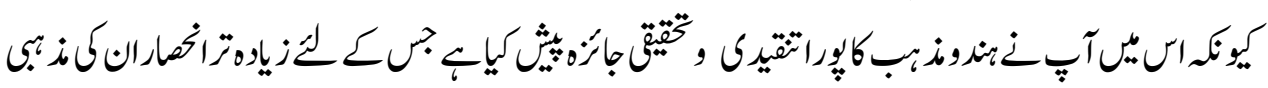

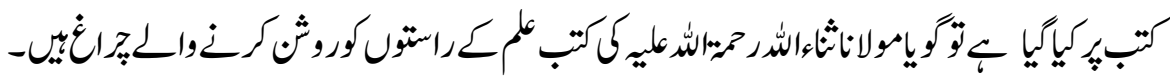

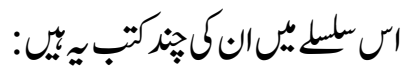

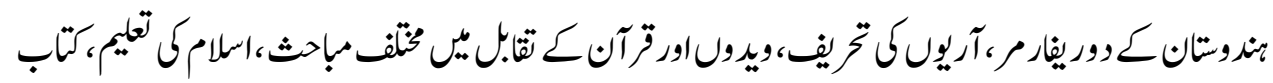

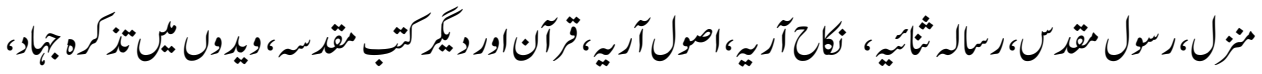

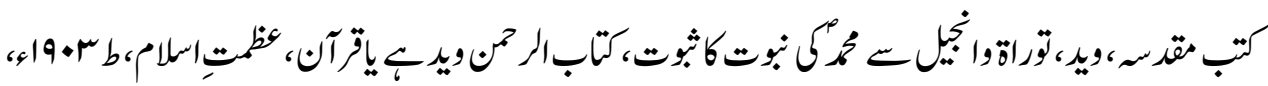

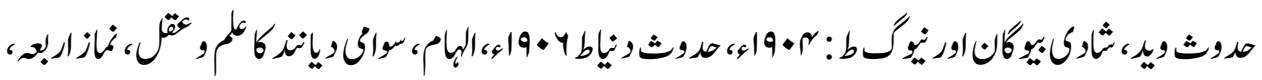

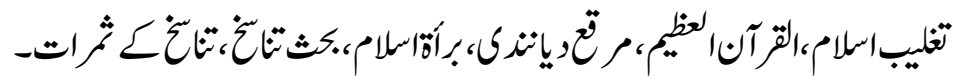

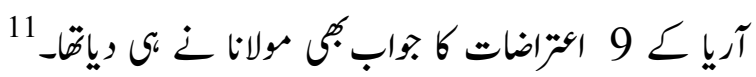

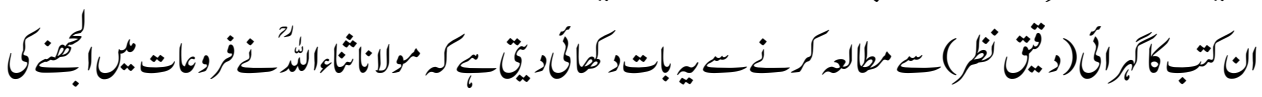

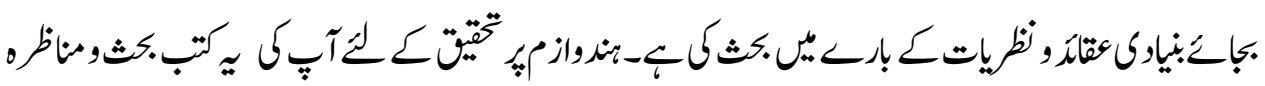

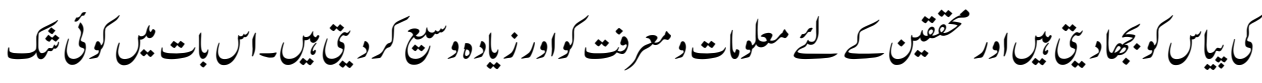

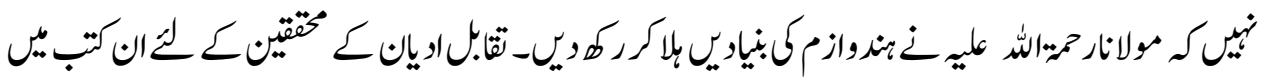

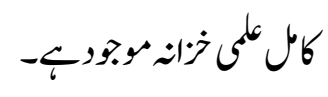

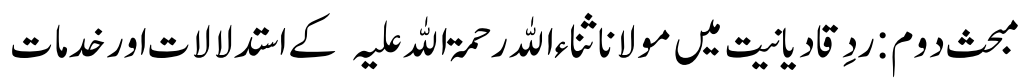

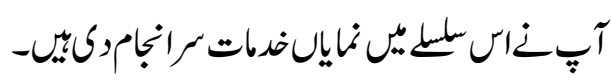

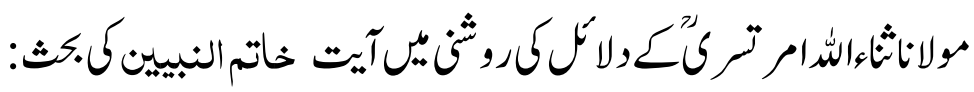

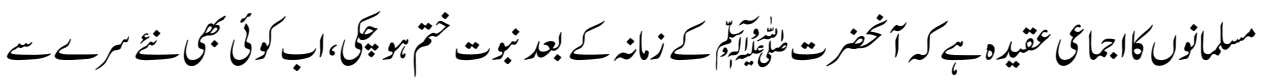

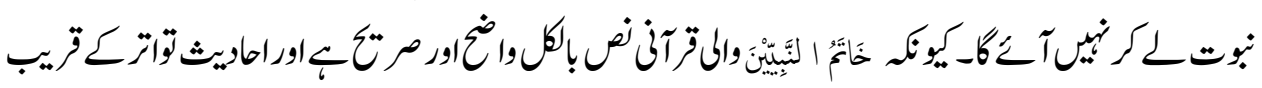




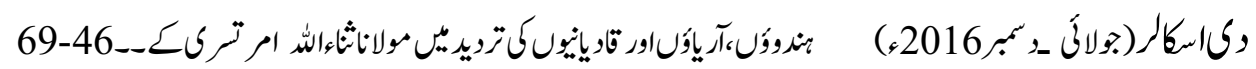

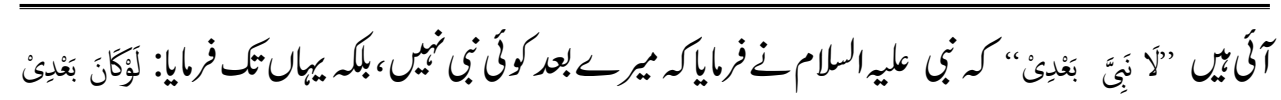

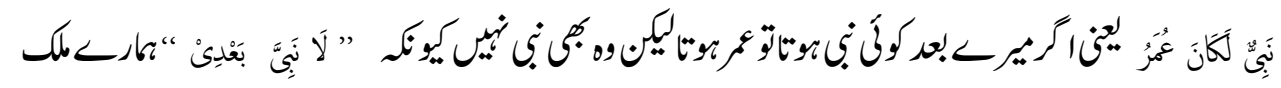

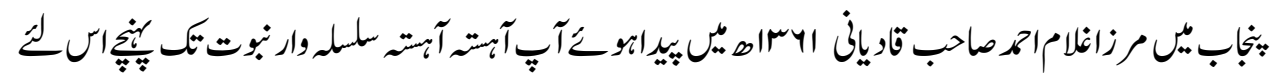

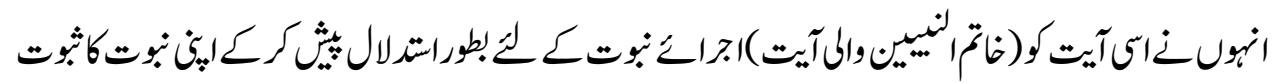

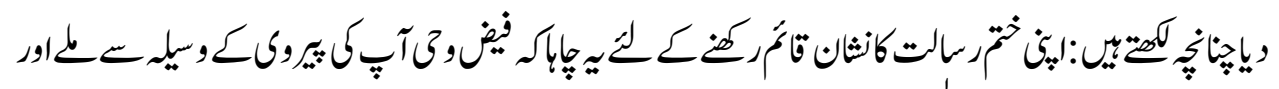

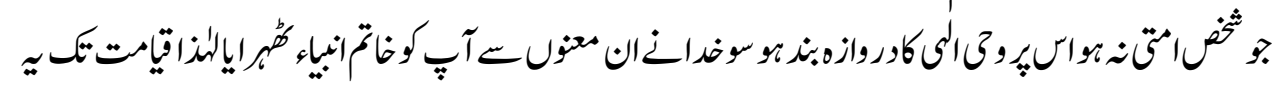

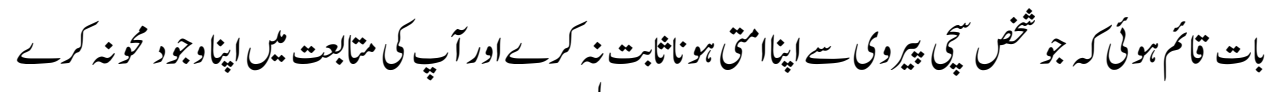

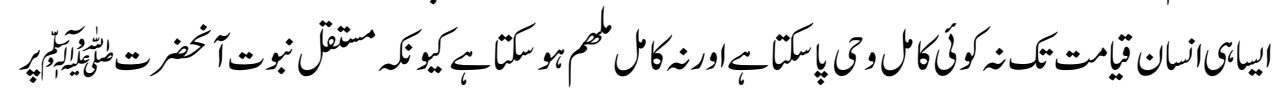

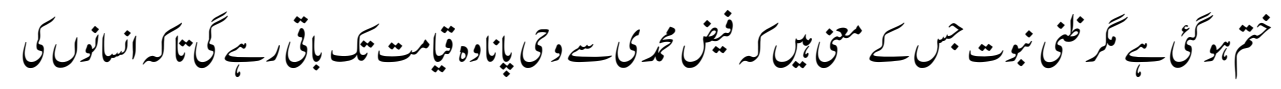

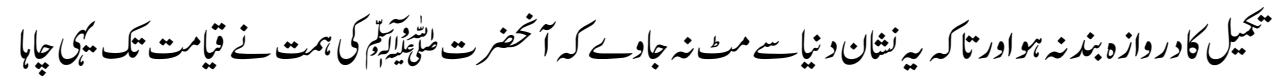

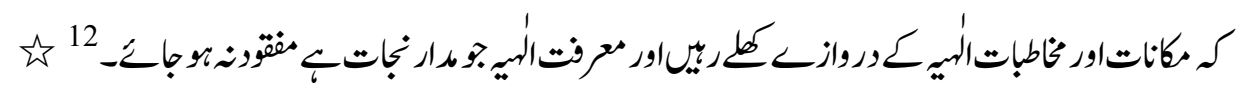

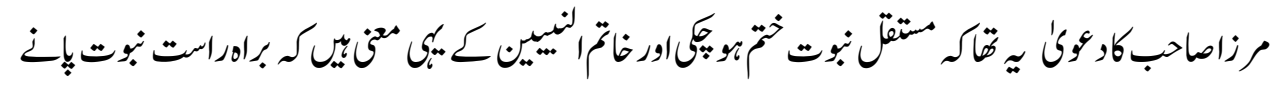

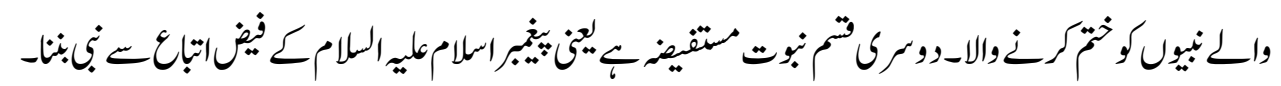

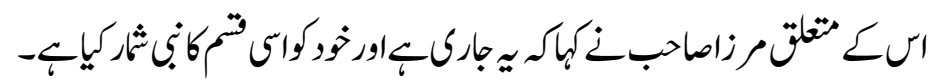

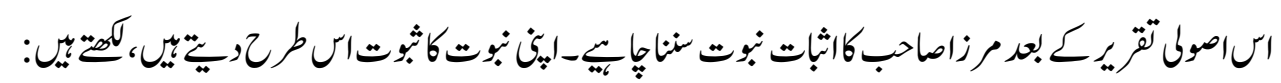

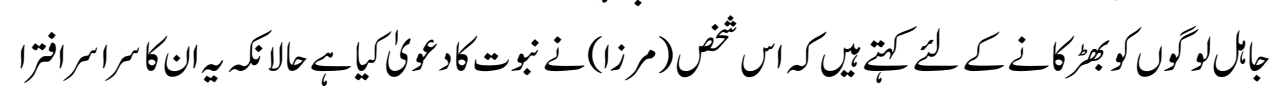

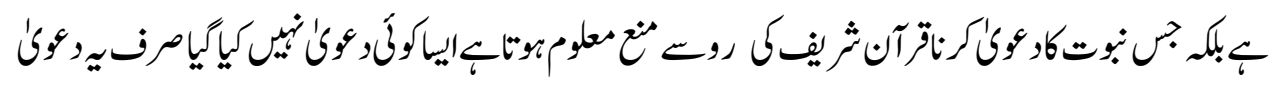

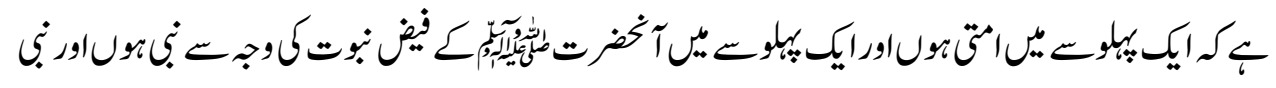

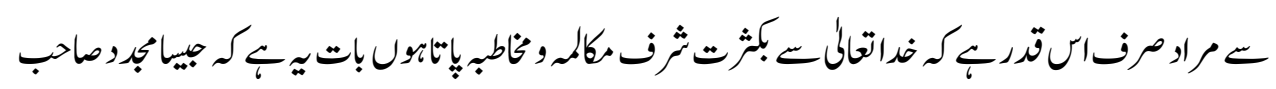

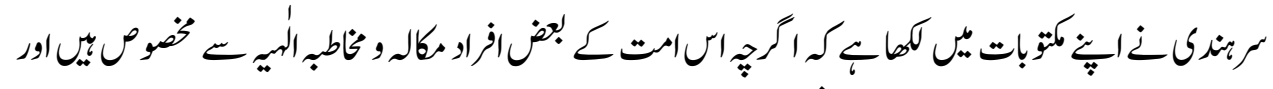

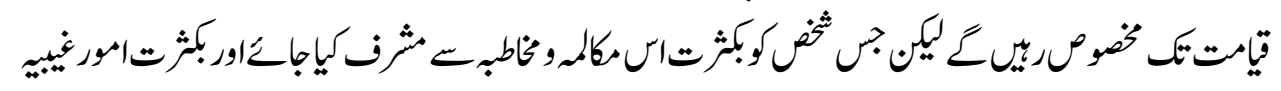

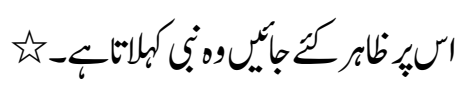

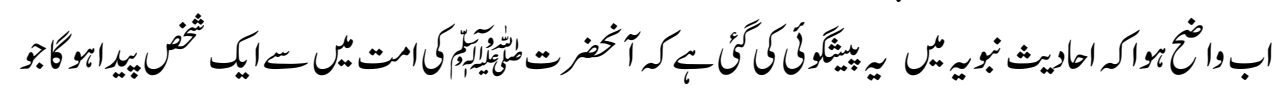

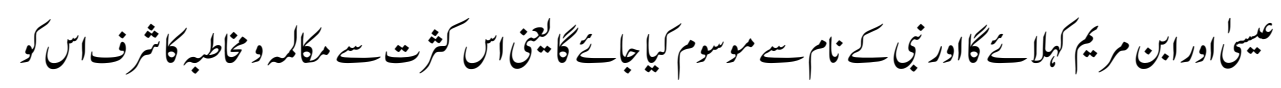




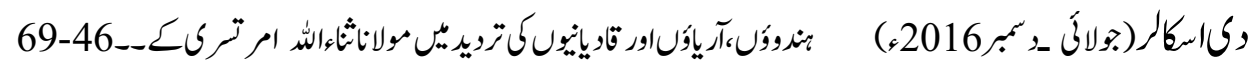

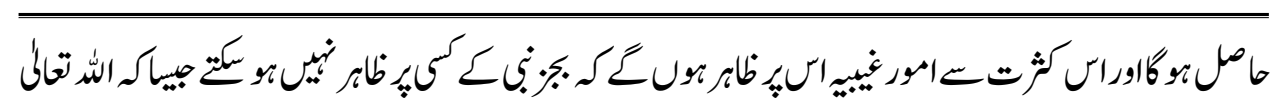
ن

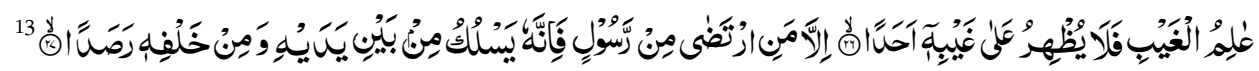

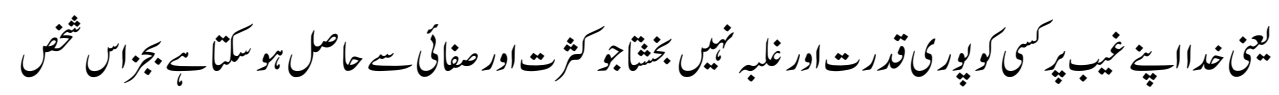

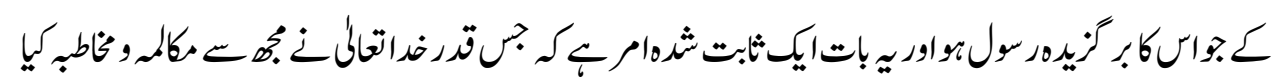

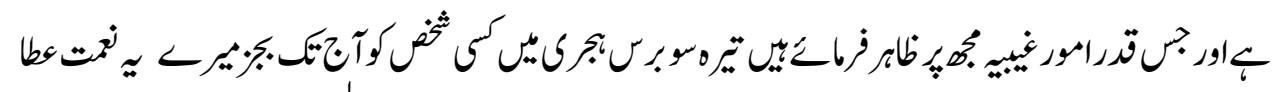

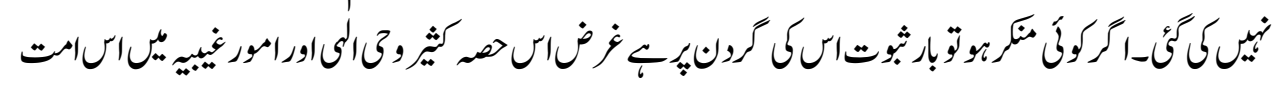

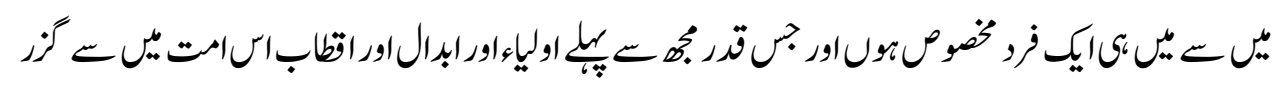

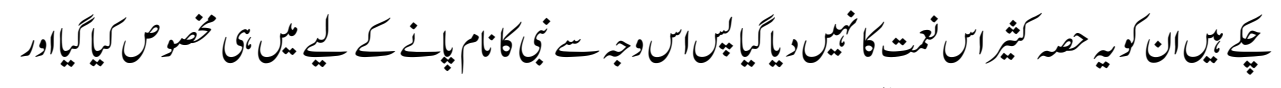

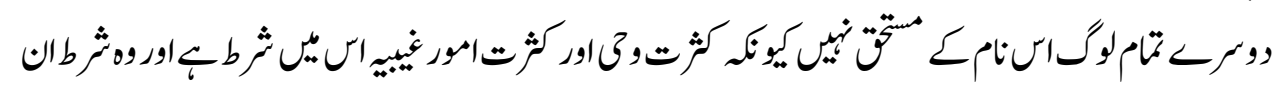

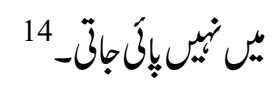

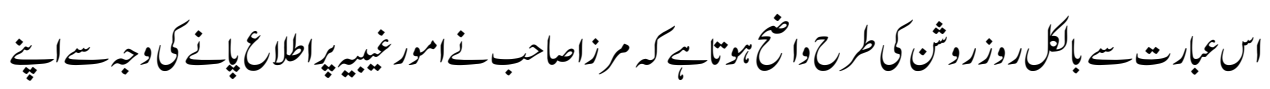

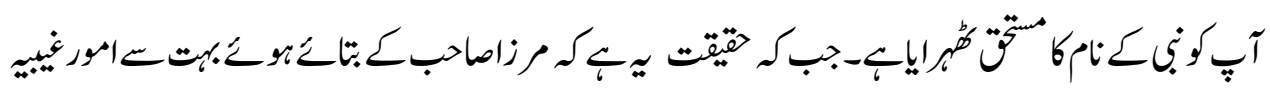

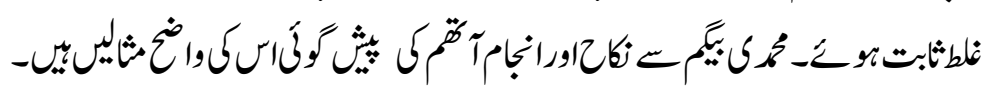

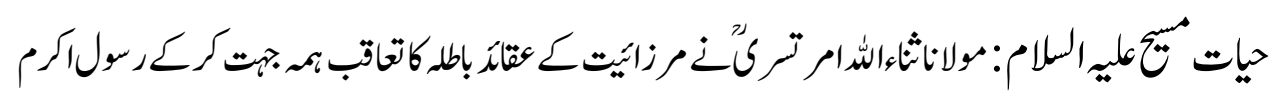

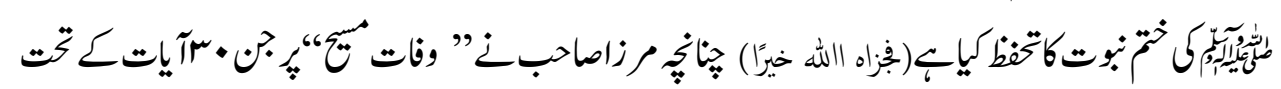

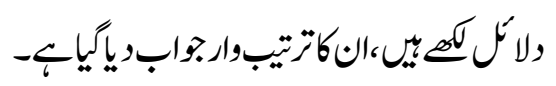

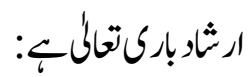

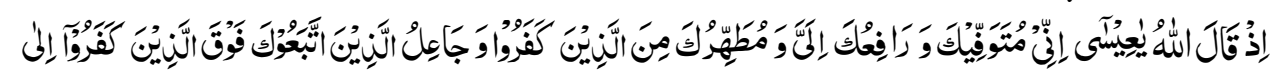

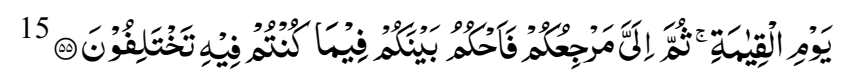

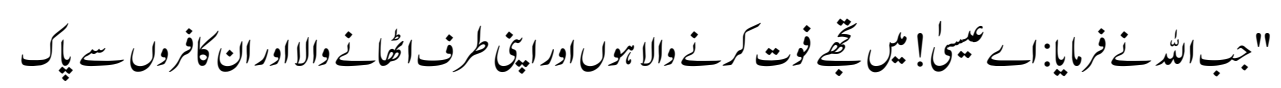

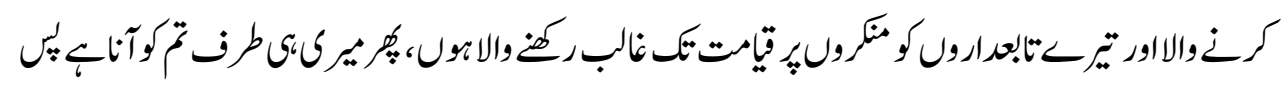

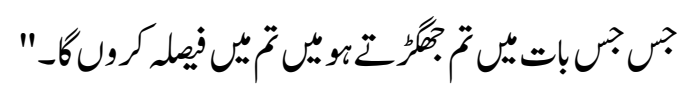

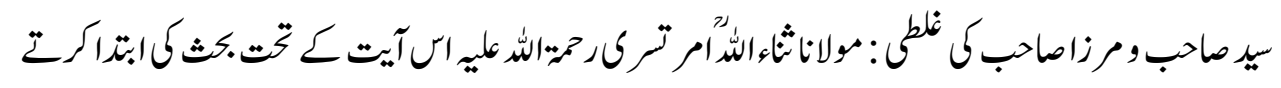




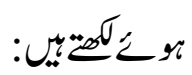

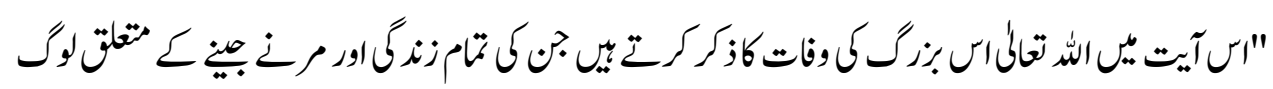

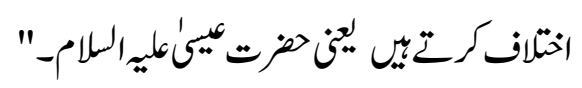

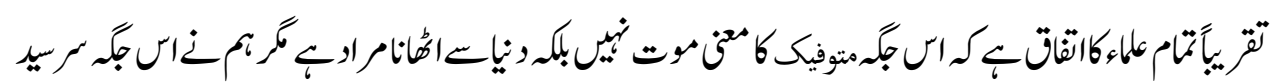

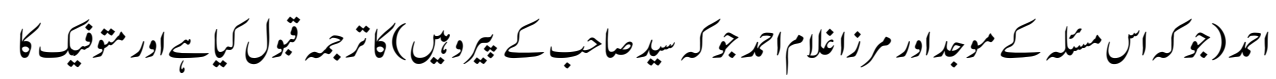

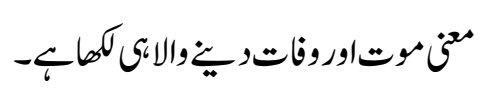

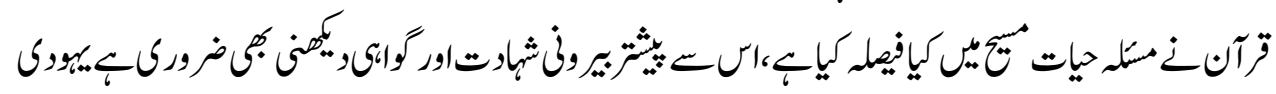

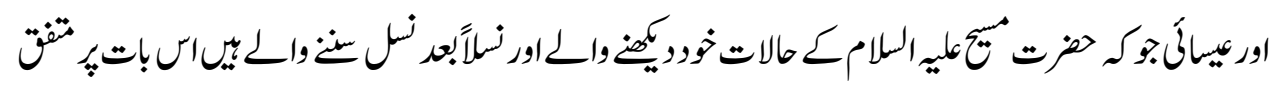

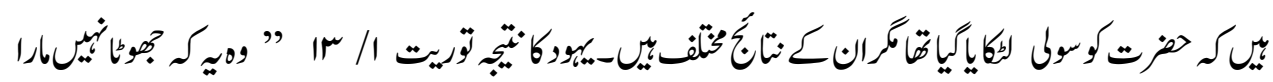

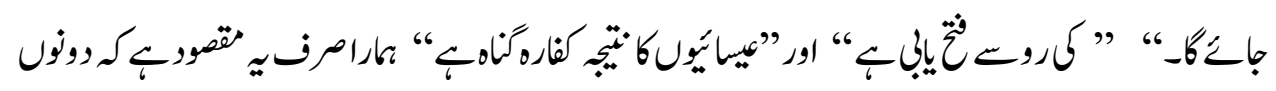

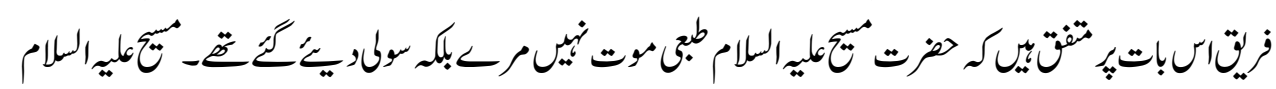

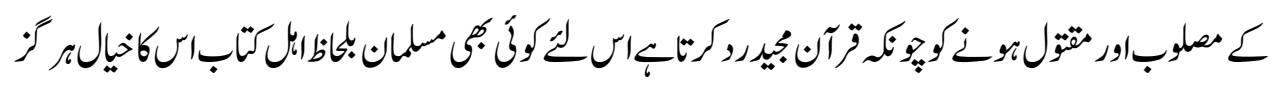

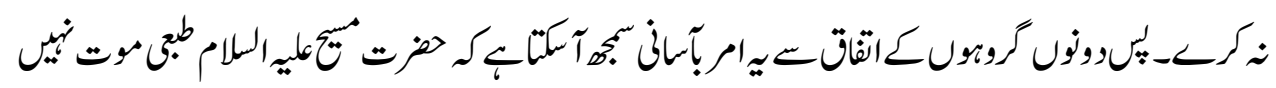

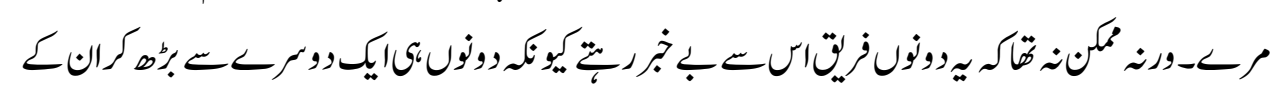

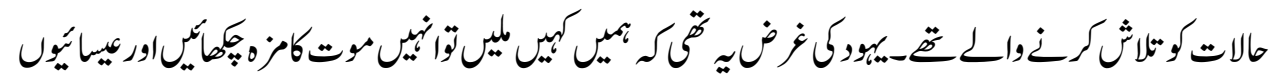

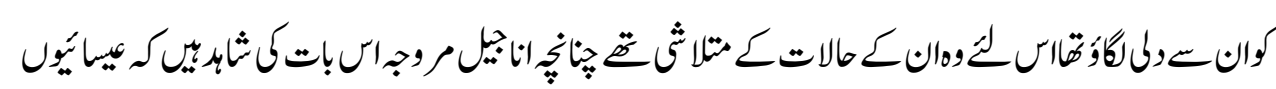

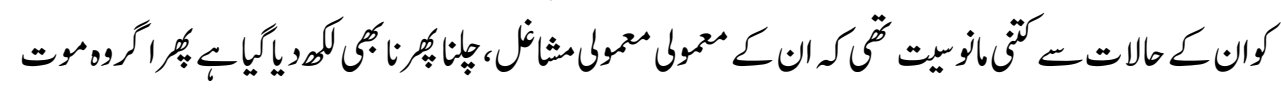

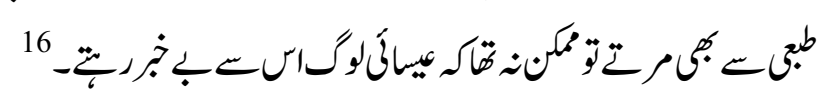

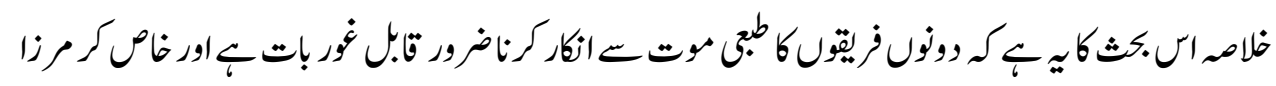

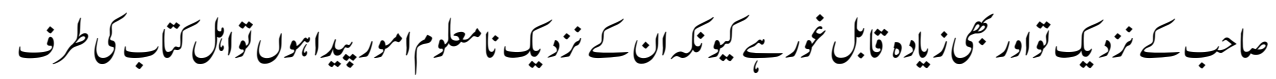

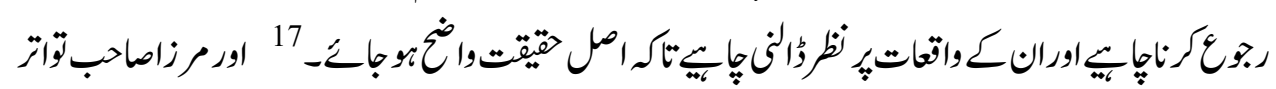

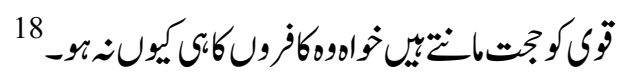

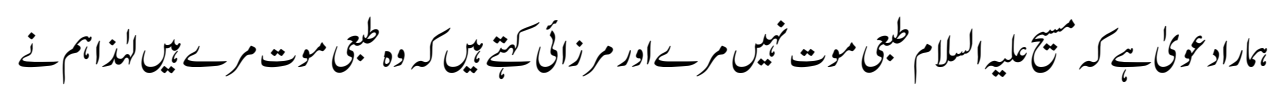

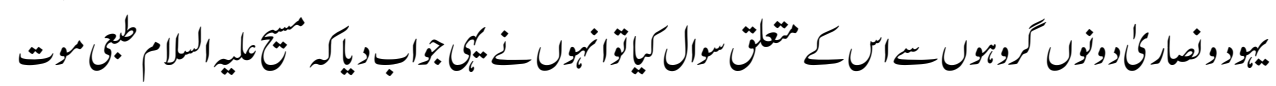




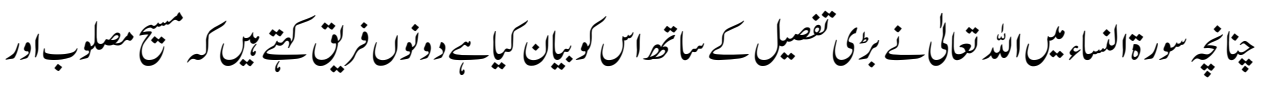

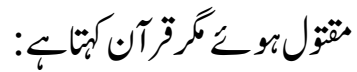

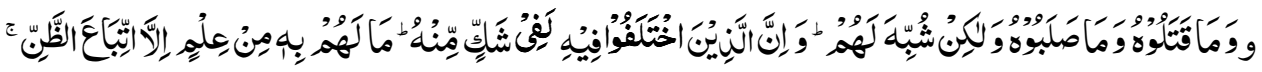

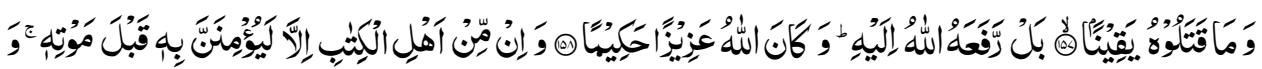

19

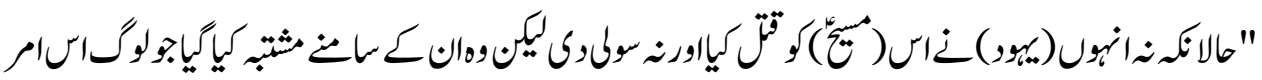

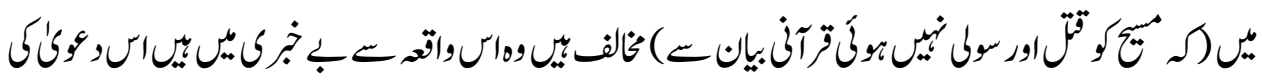

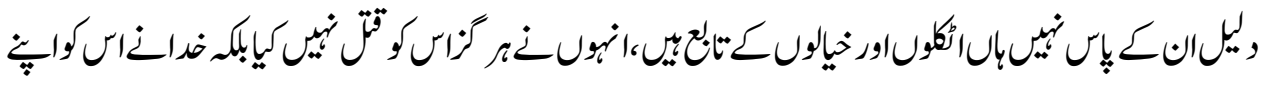

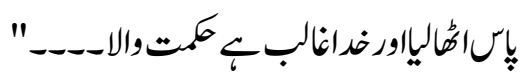

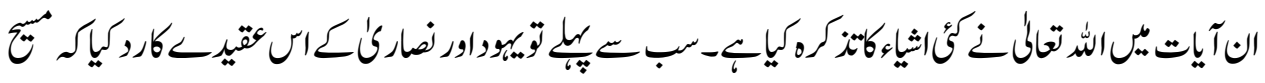

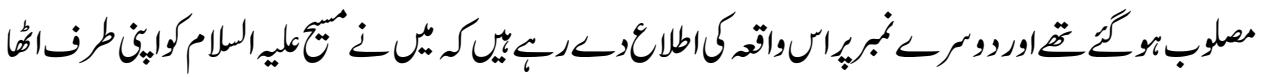

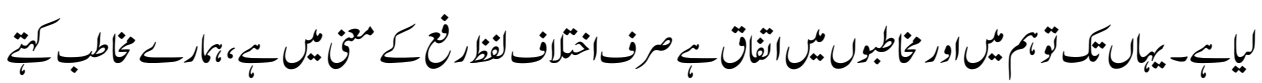

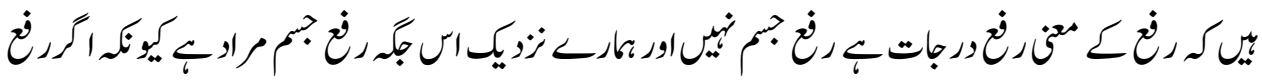

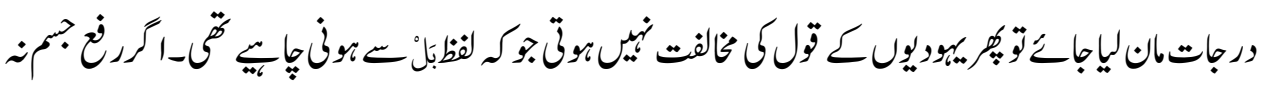

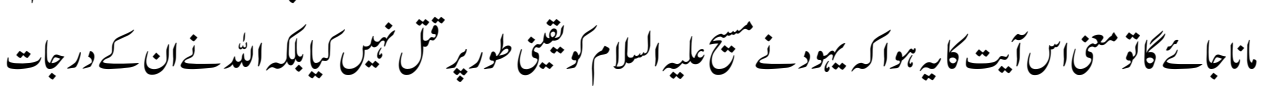

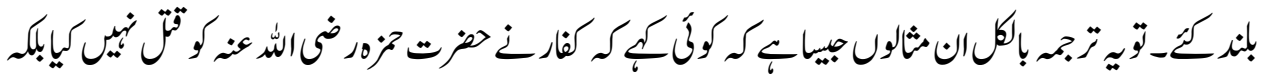

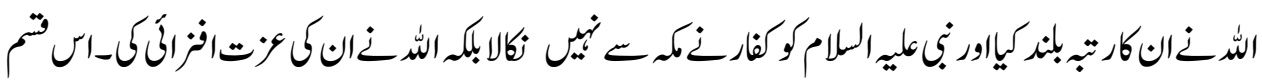

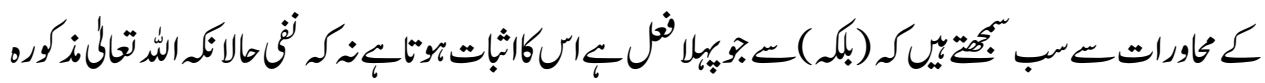

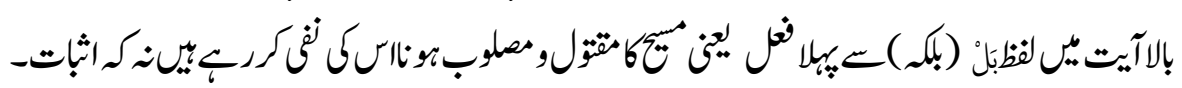

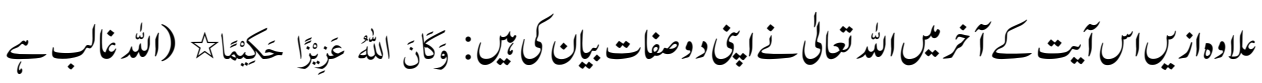

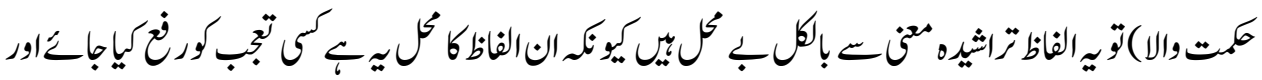

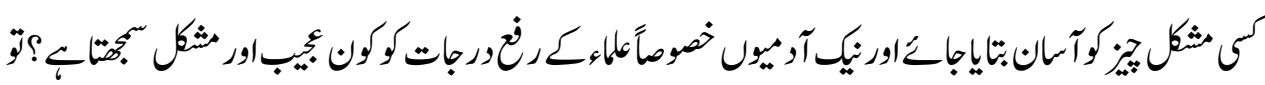

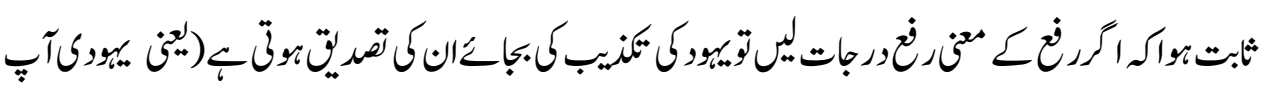




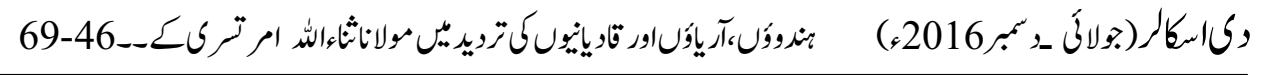

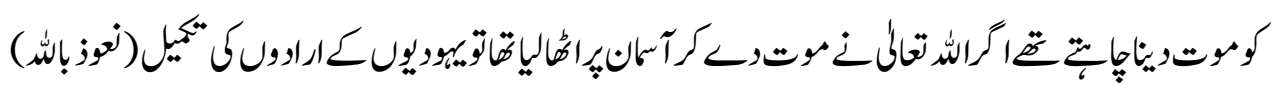

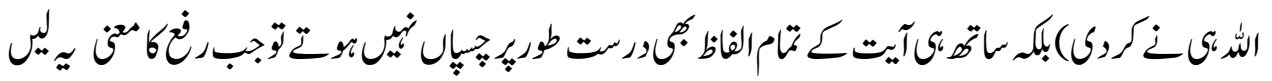

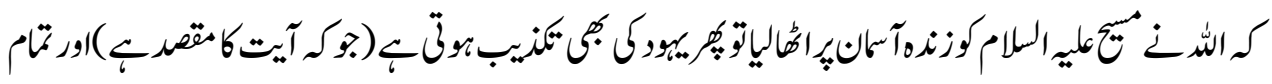

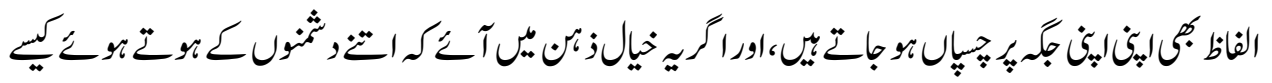

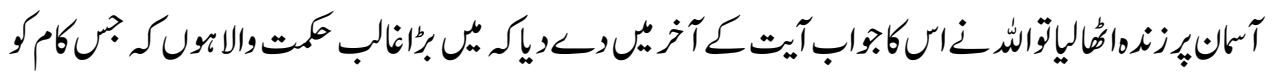

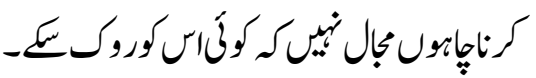

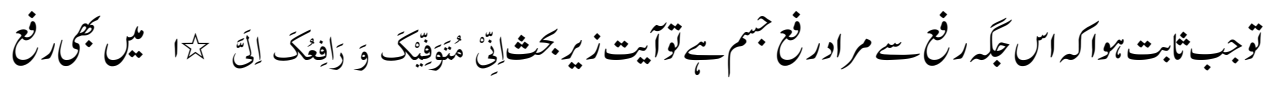



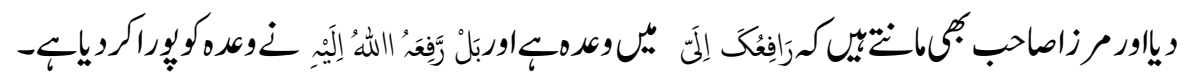

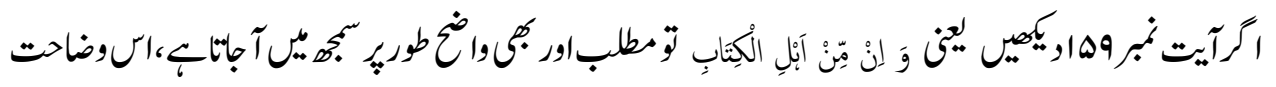

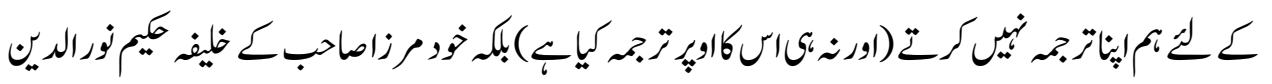

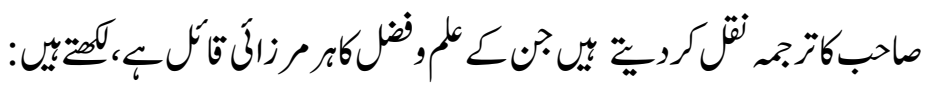

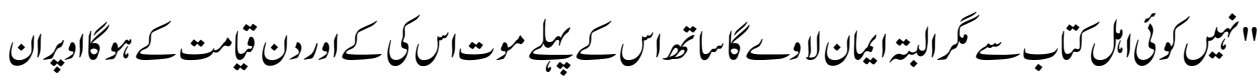

ك كَ" 20

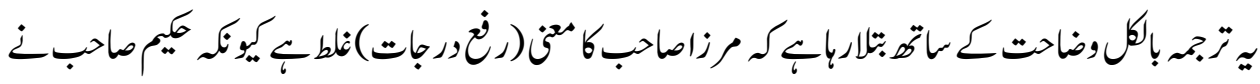

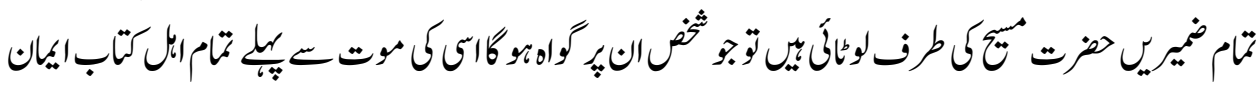

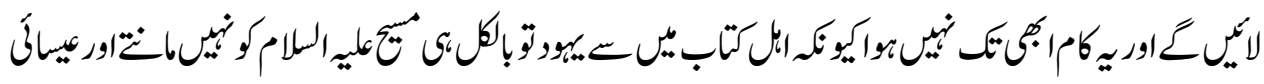

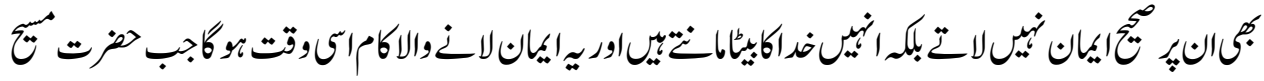

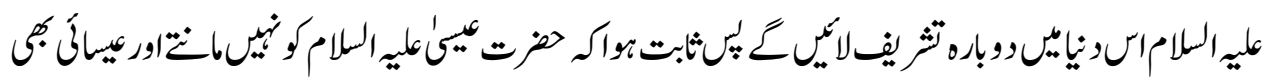

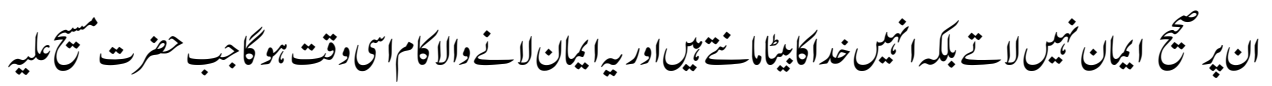

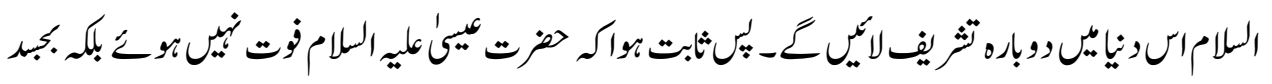

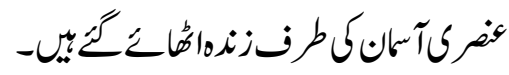

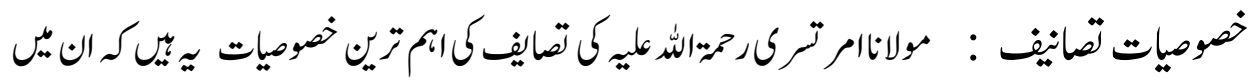

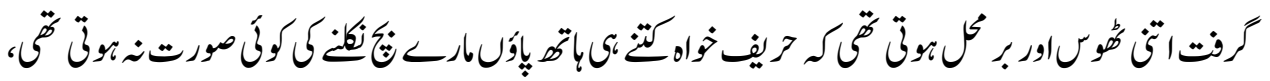




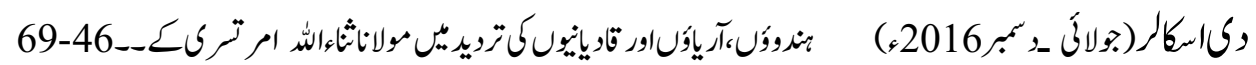

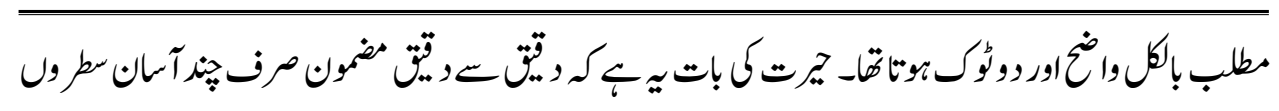

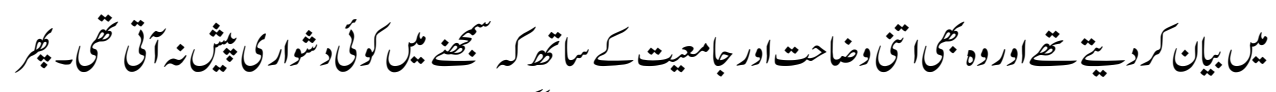

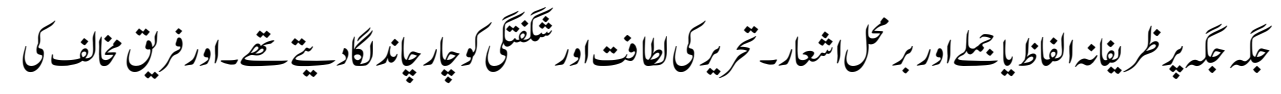

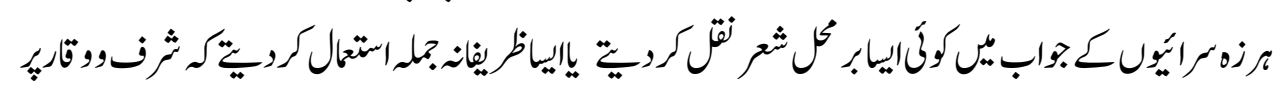

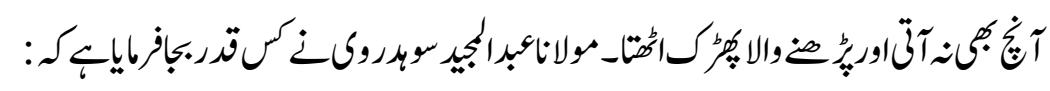

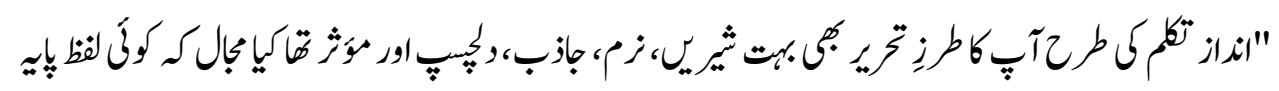

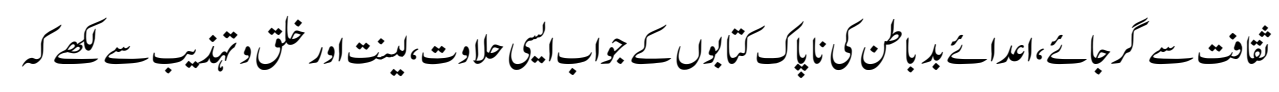

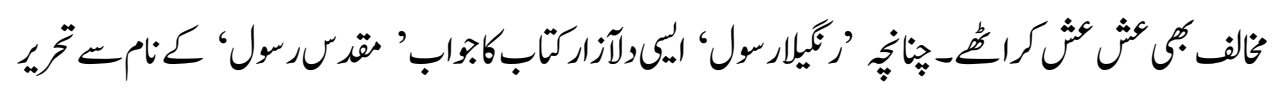

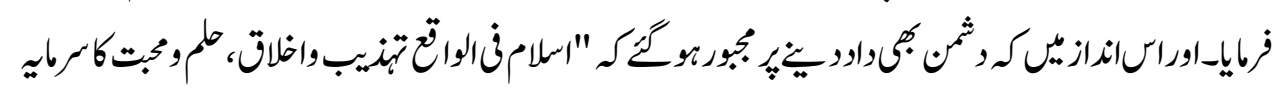

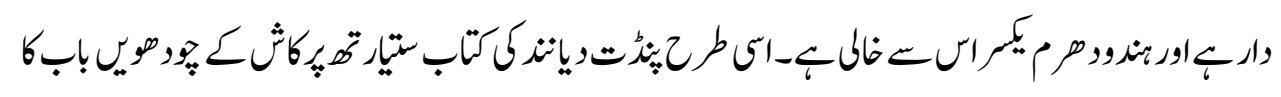

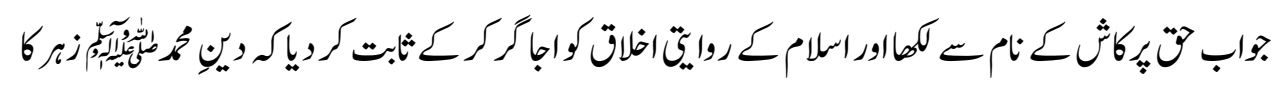

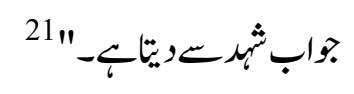

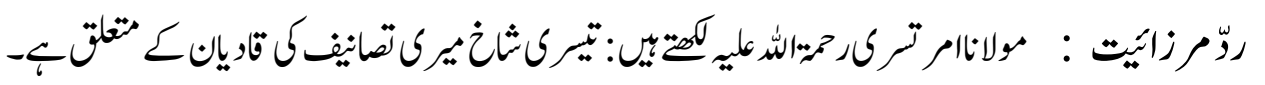

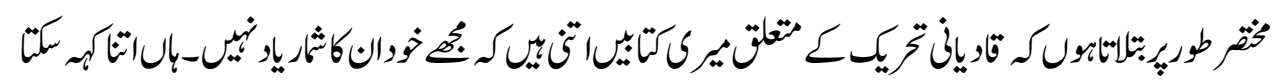

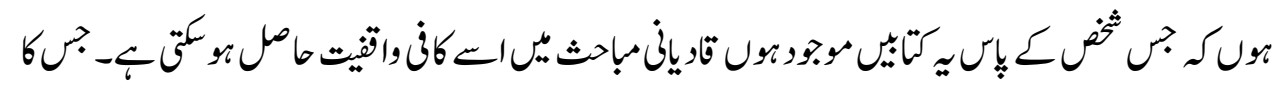

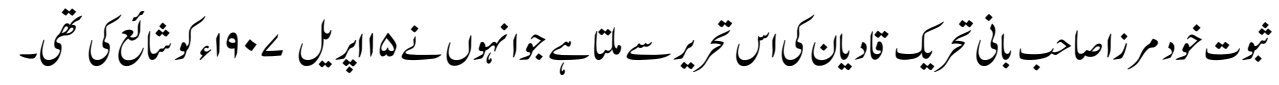

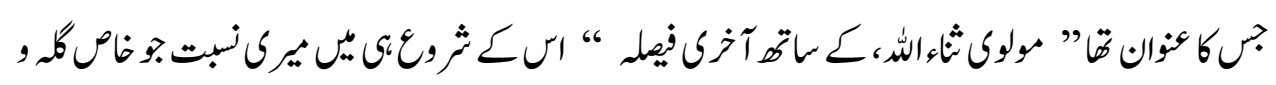

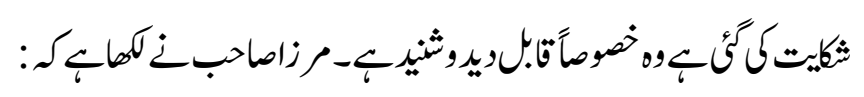

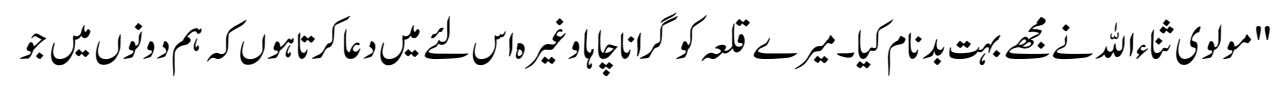

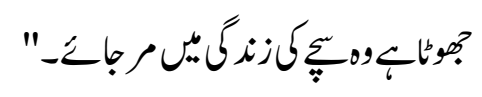

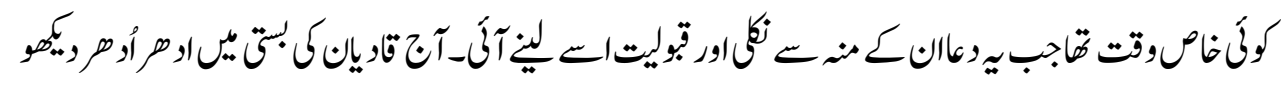

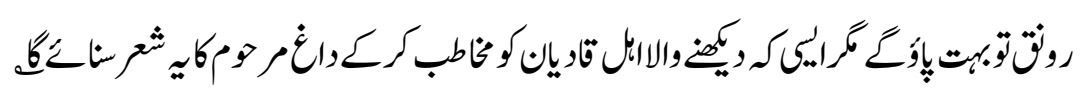

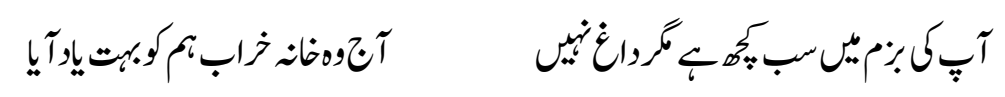




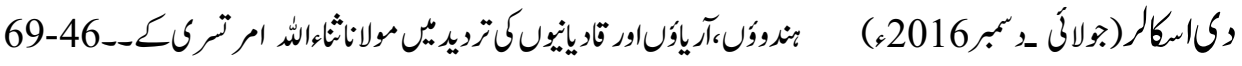

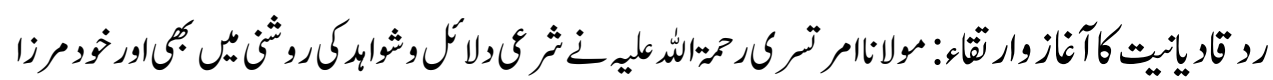

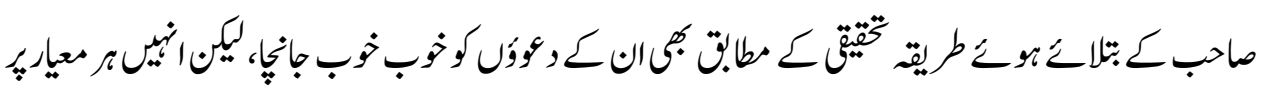

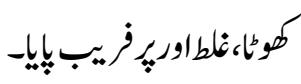

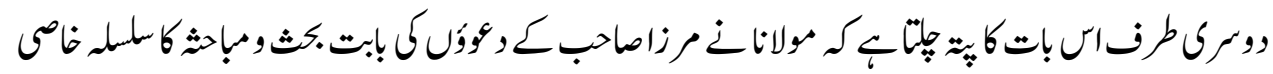

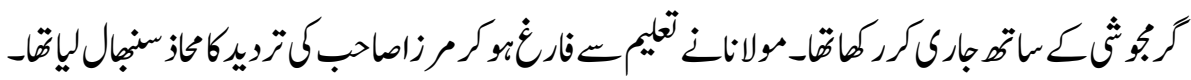

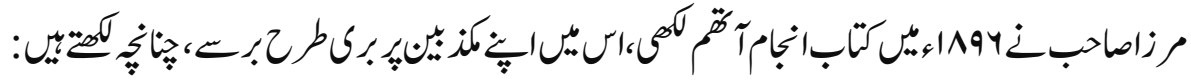

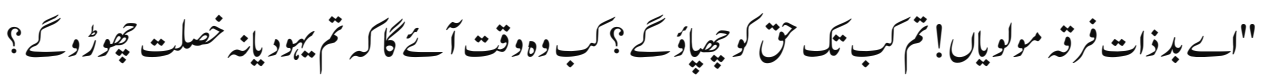

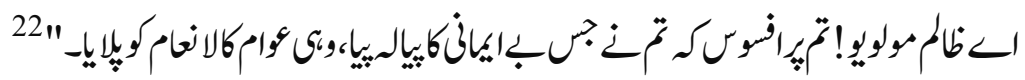

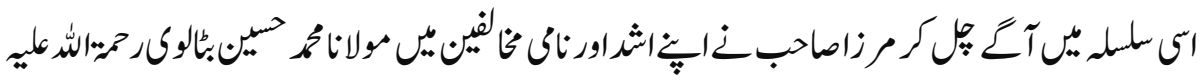

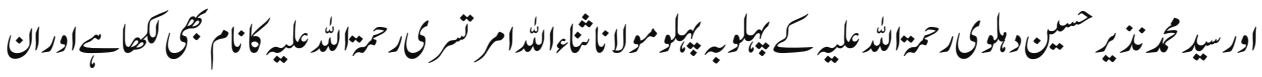

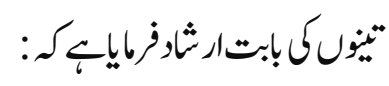

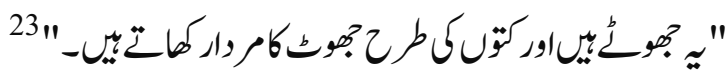

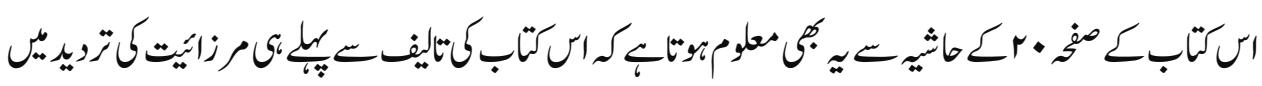

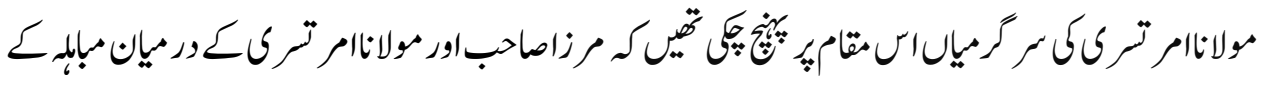

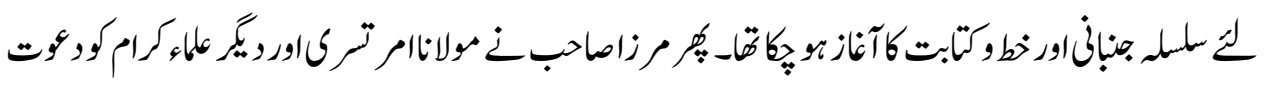

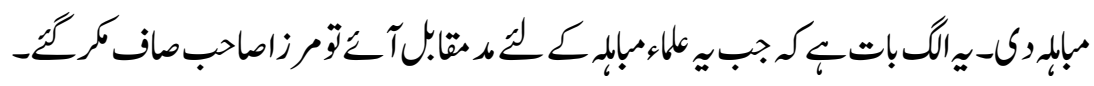

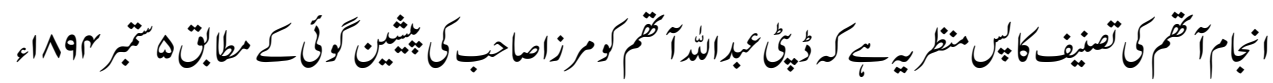

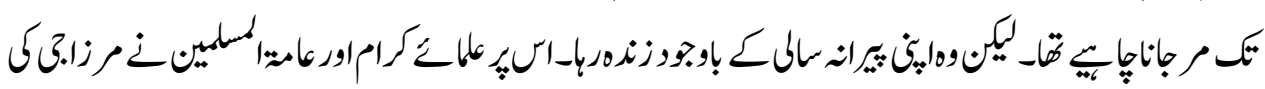

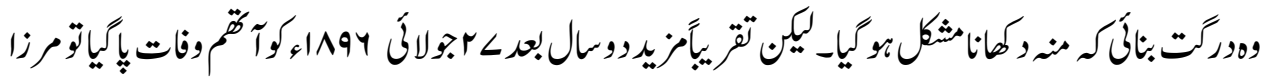

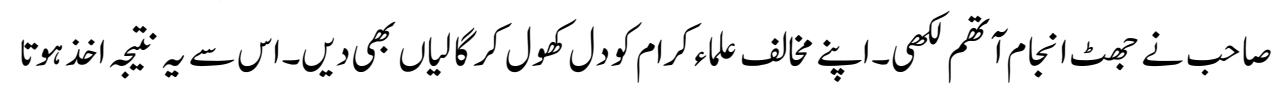

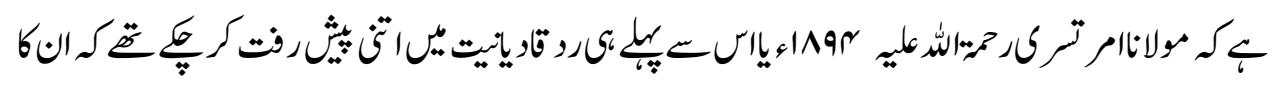

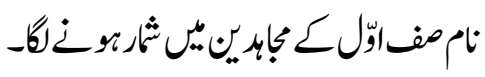

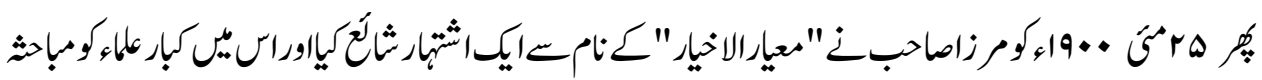

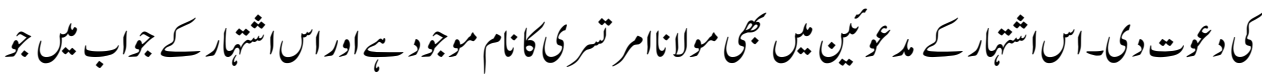




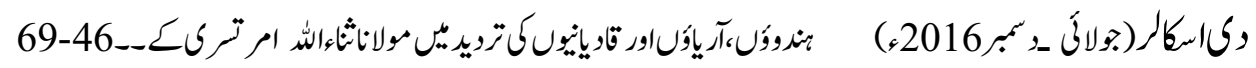

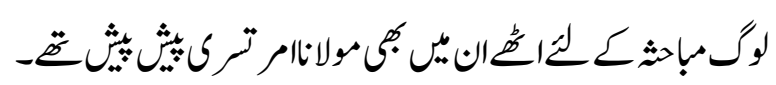

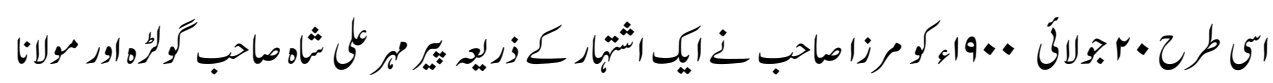

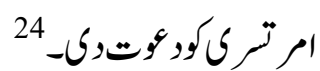

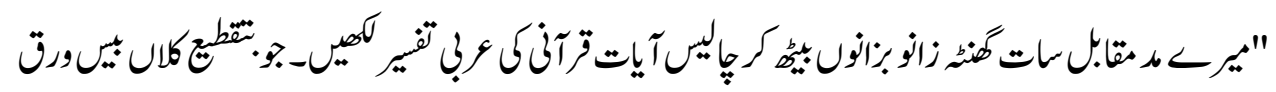

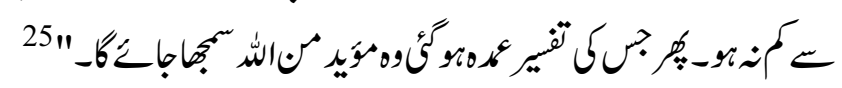

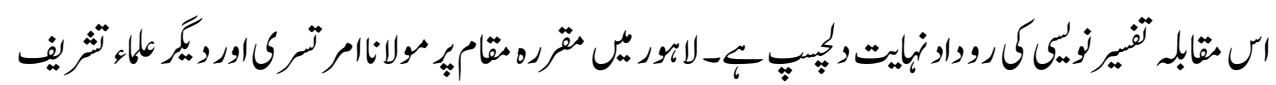

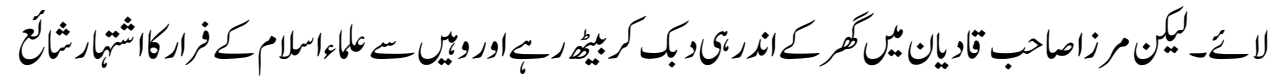
كرويا-

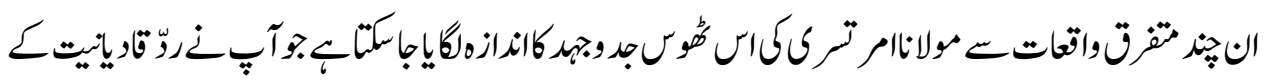

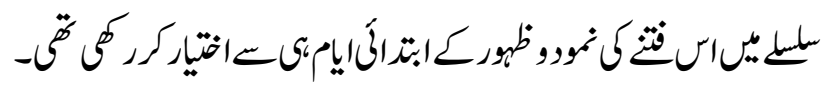

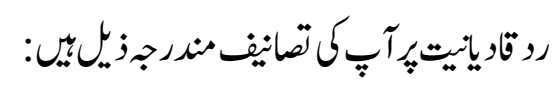

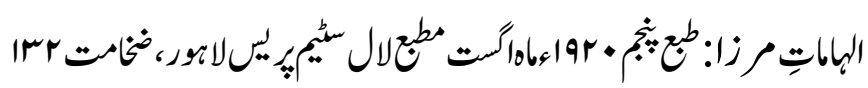

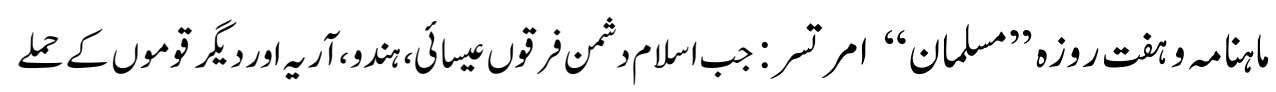

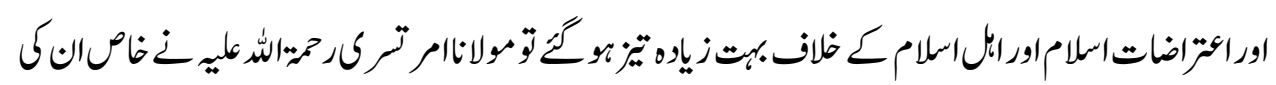

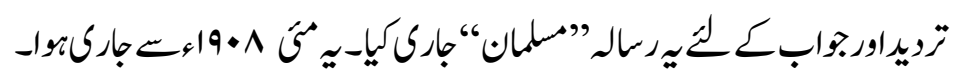

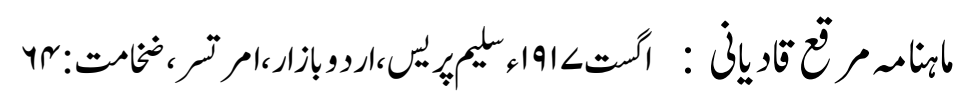

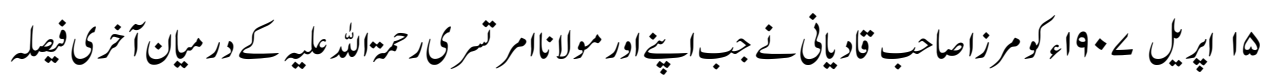

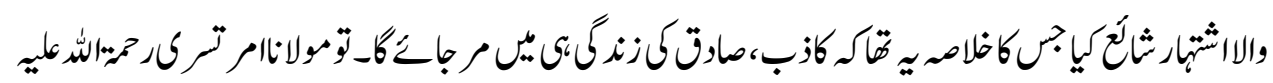

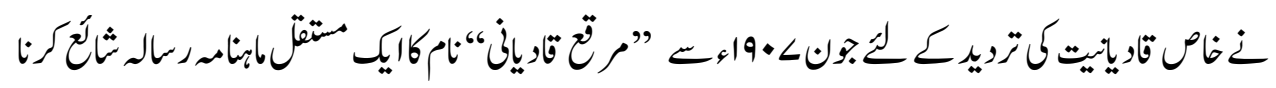

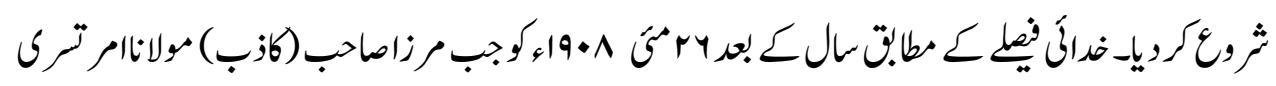

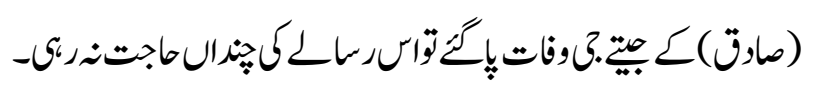

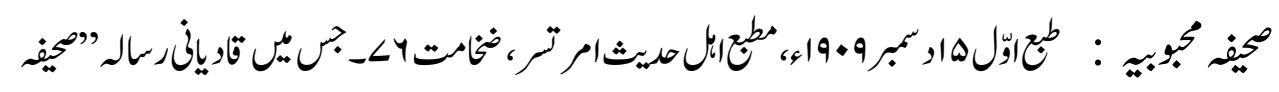

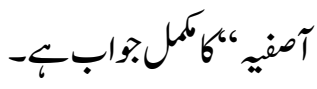




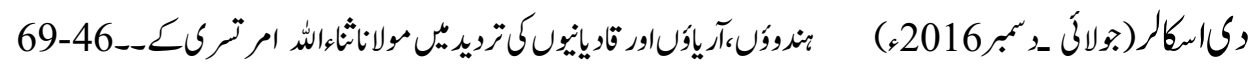

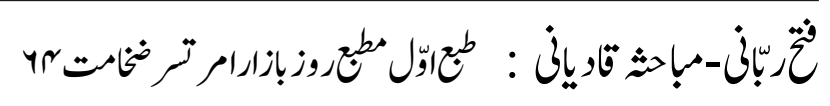

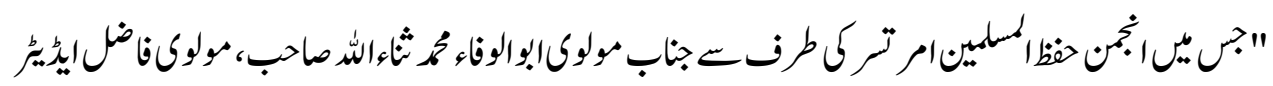

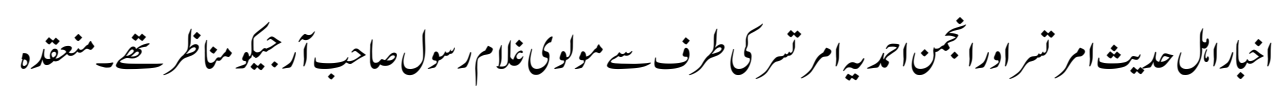

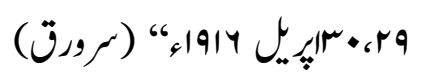

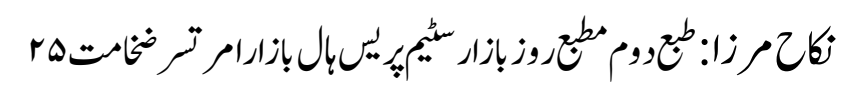

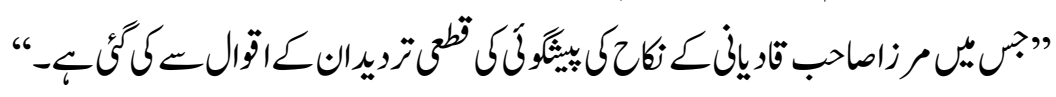

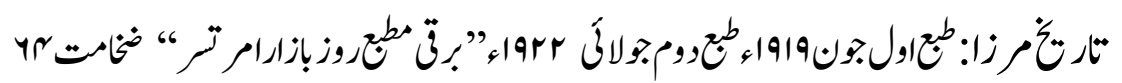

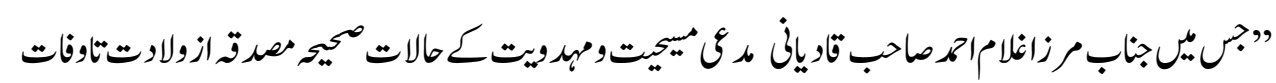
ربتيل-“

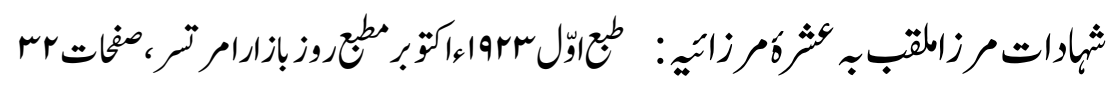

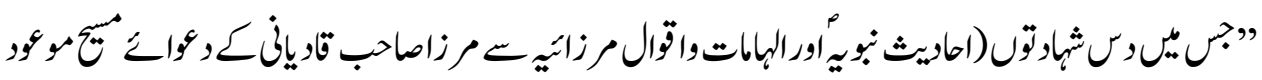

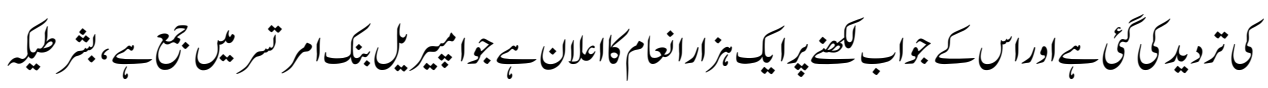

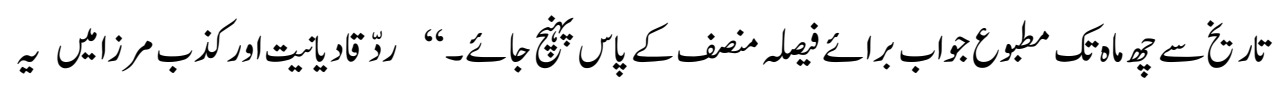

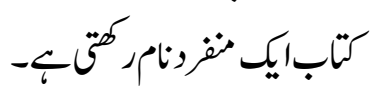

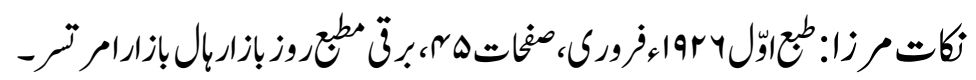

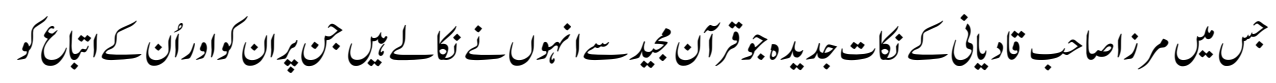

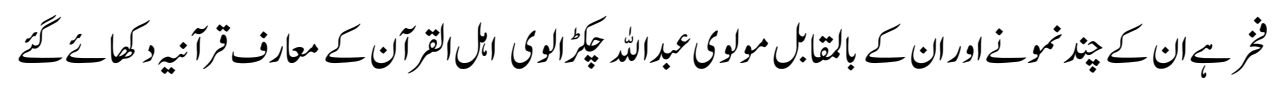

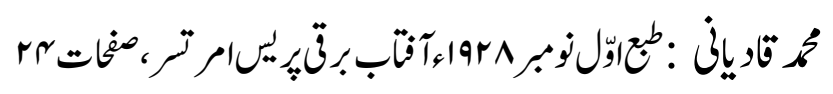

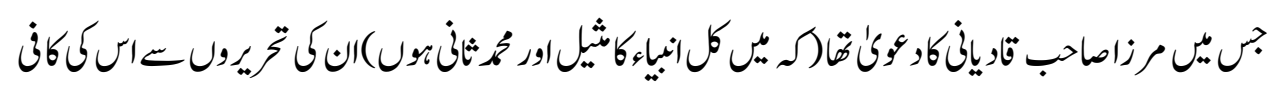

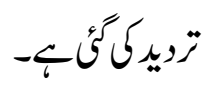

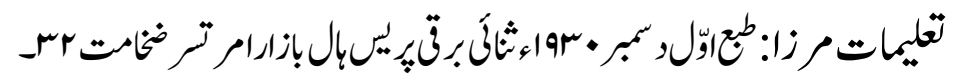

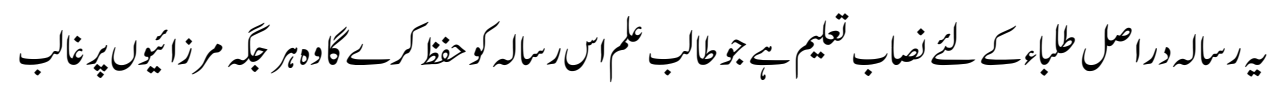




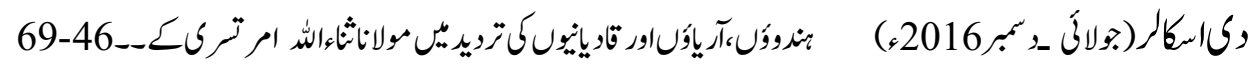

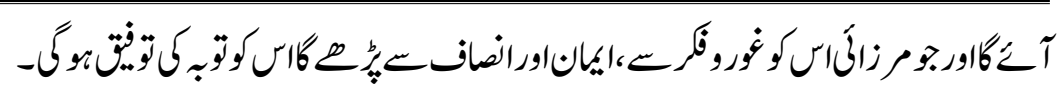

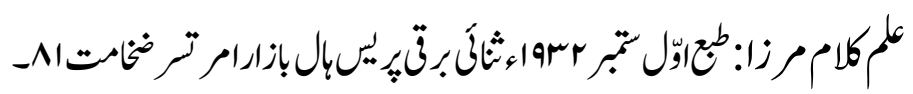

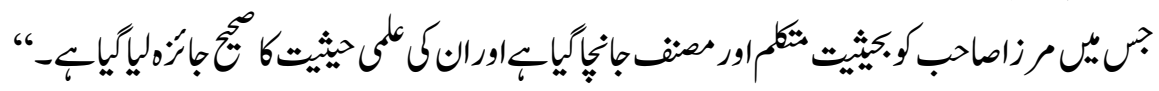

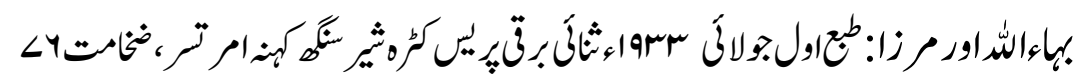

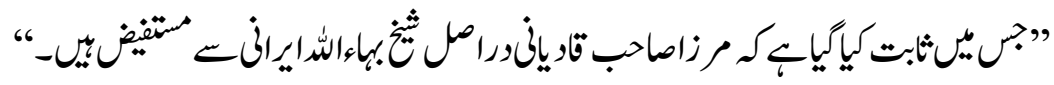

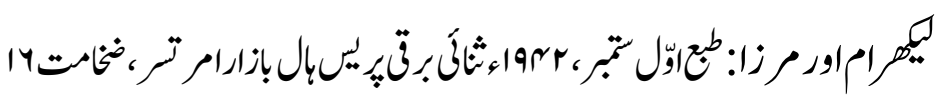

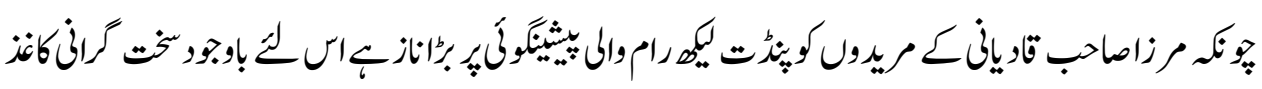

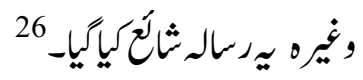

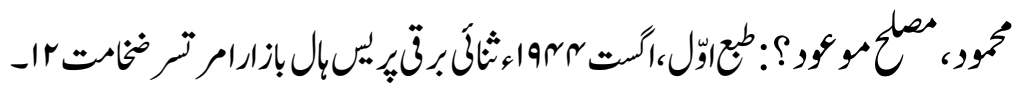

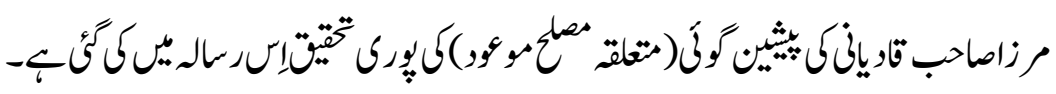

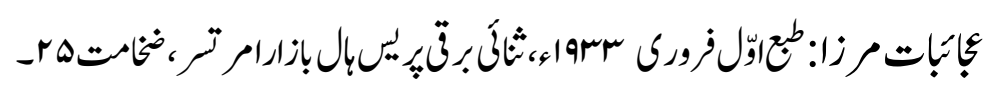

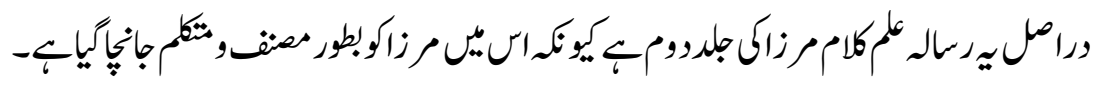

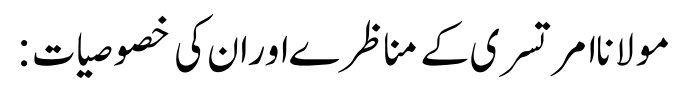

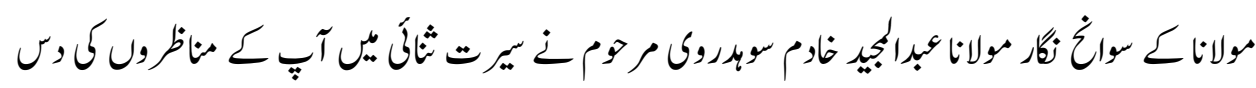

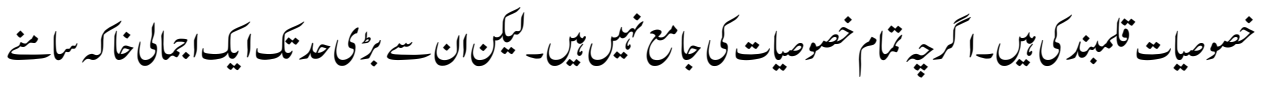

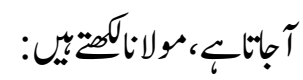

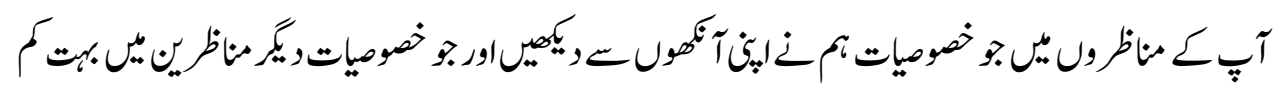

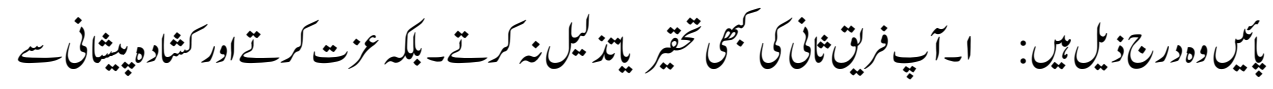

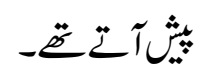

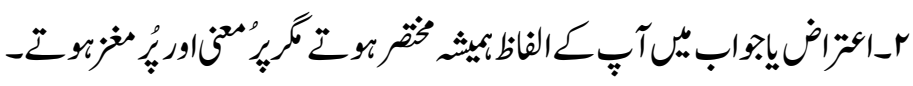

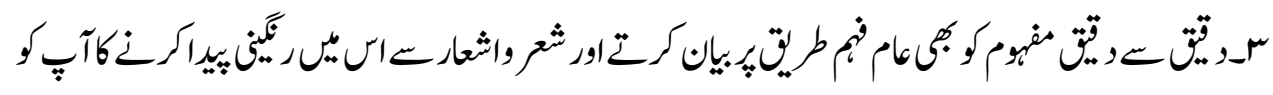
ناص ملكم ثقا-

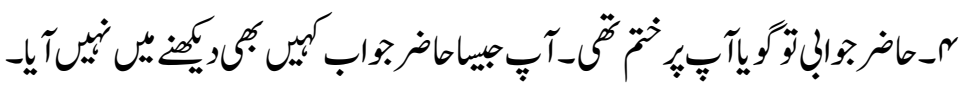




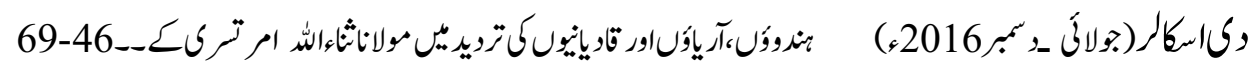

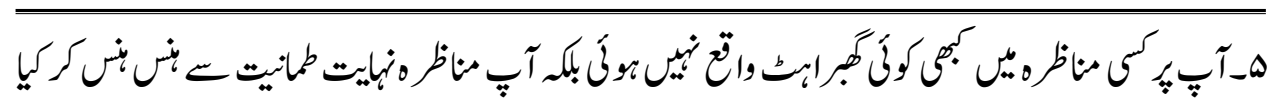
$-\ddot{E} z$

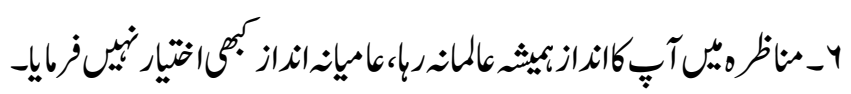

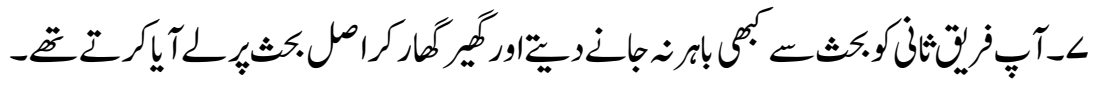

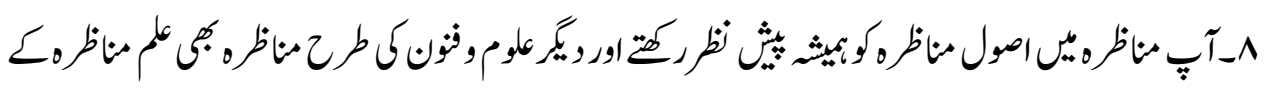
اصوليركر

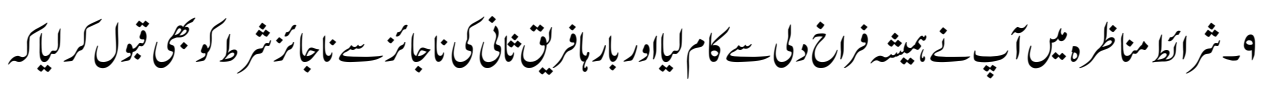

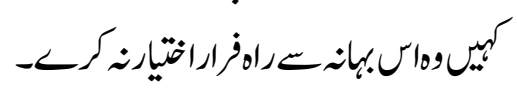

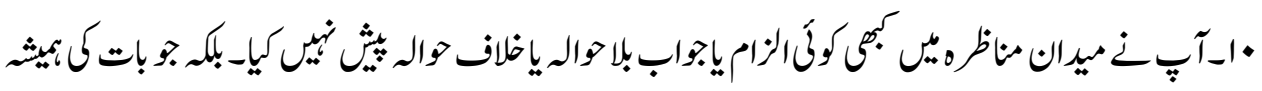

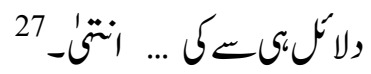

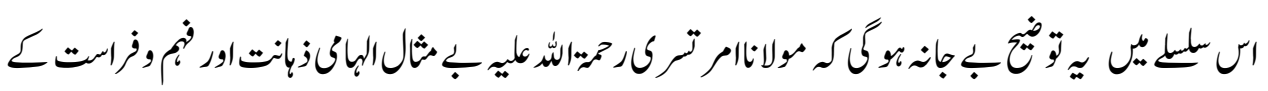

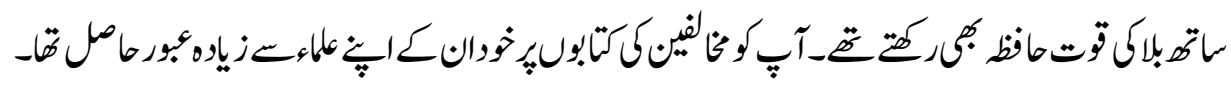

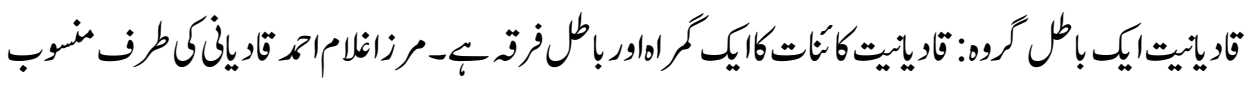

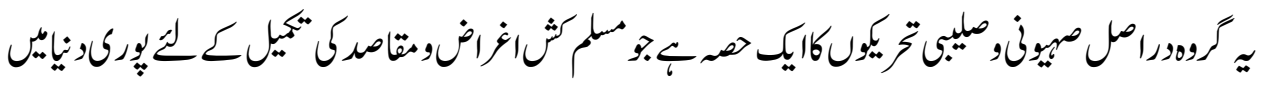

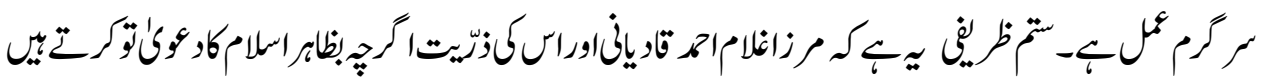

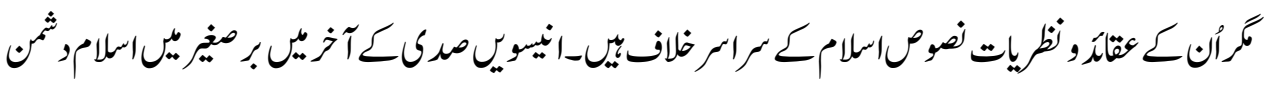

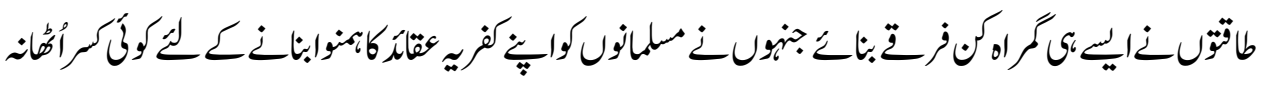

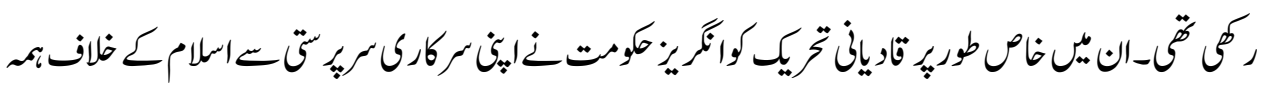

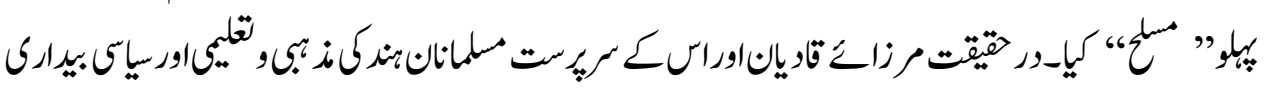

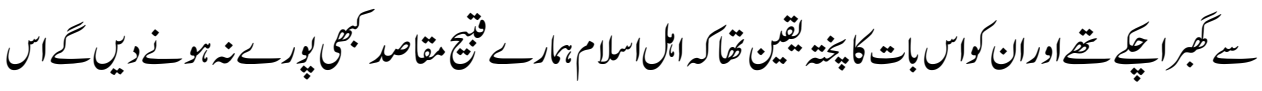

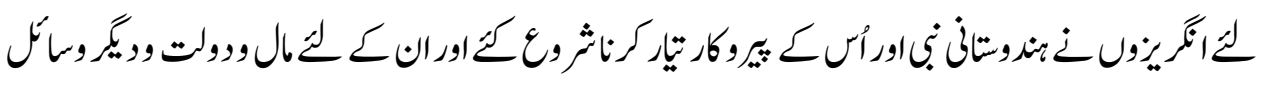

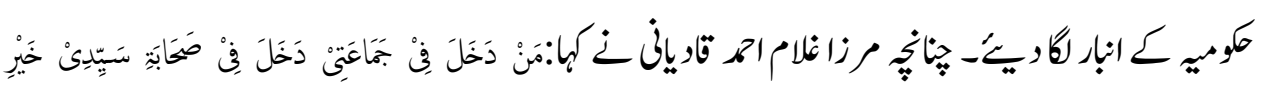

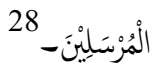

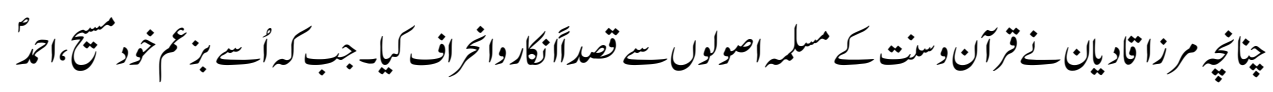




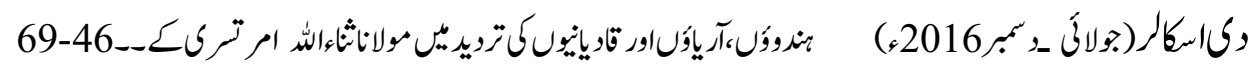

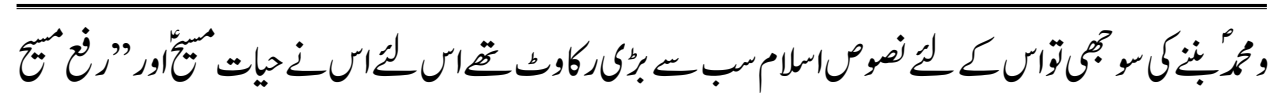

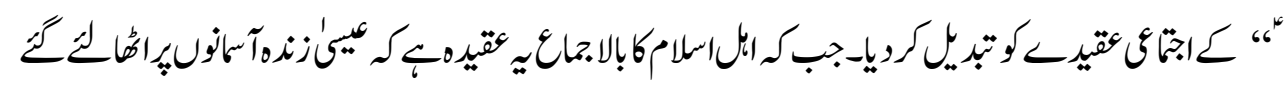

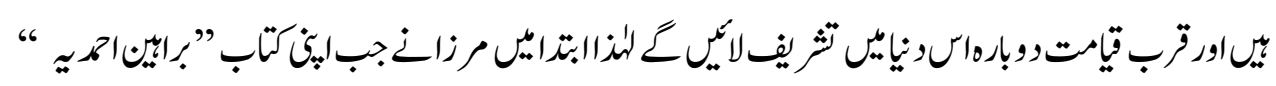

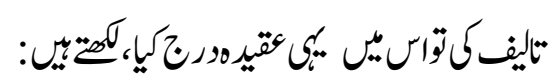

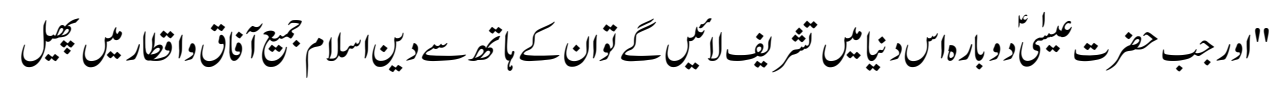
جإ- 29

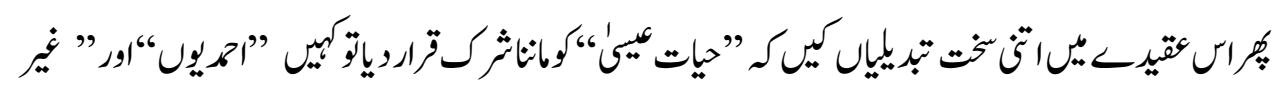

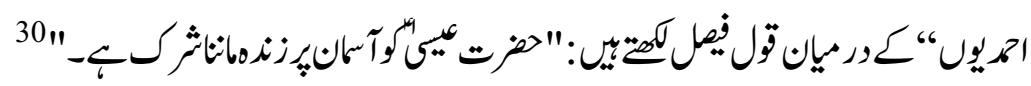

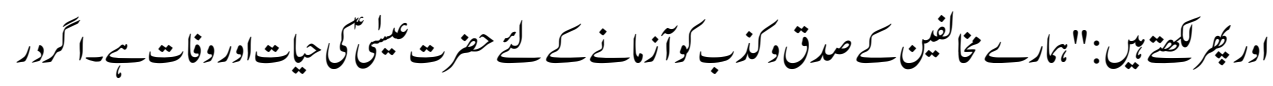

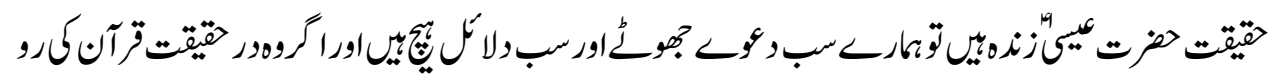

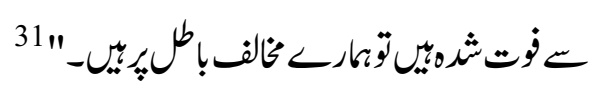

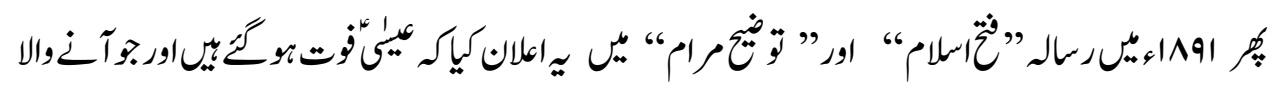

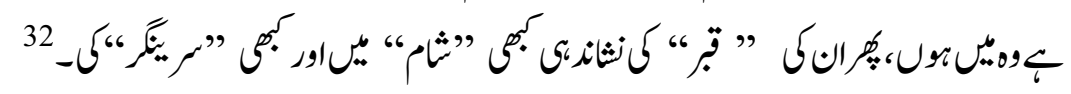

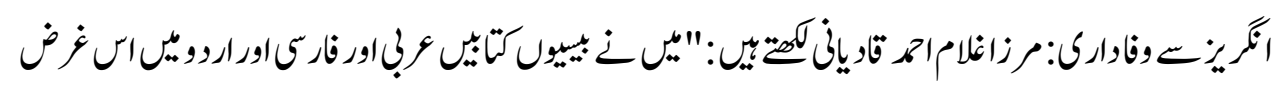

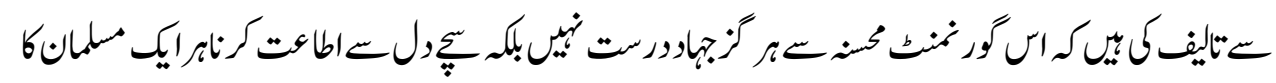

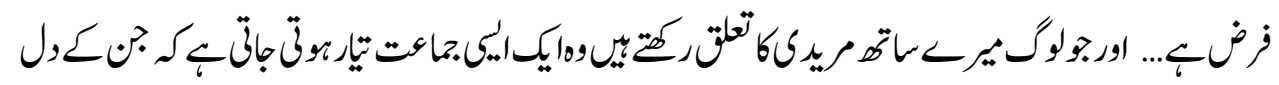

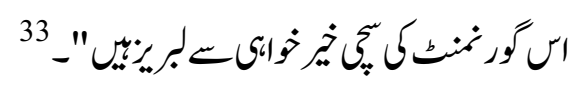

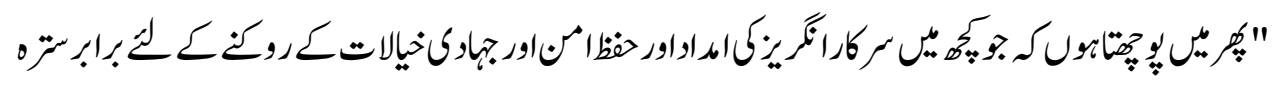

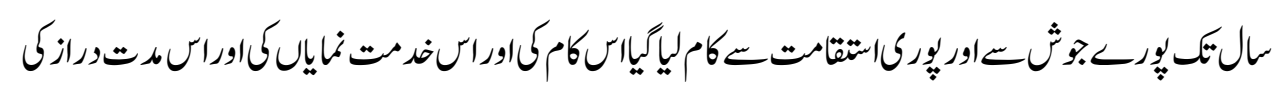

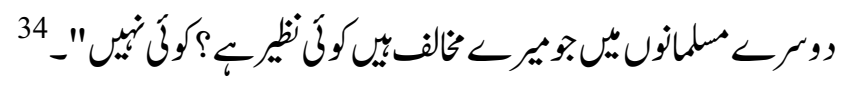

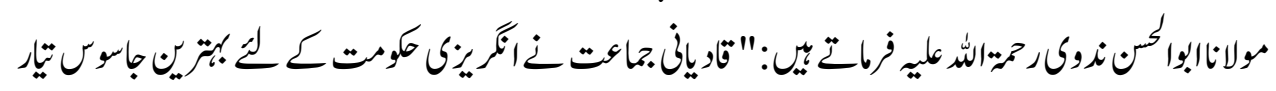

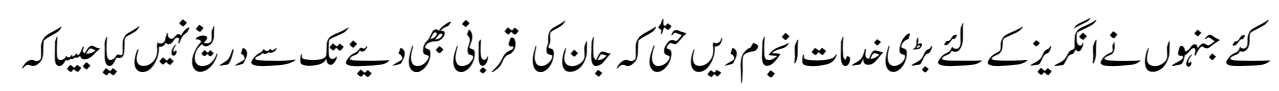

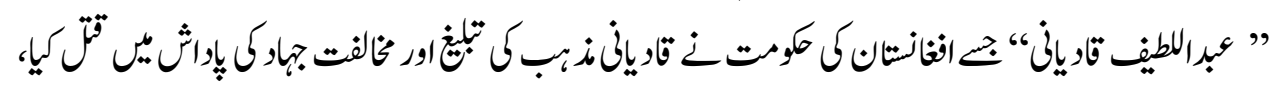

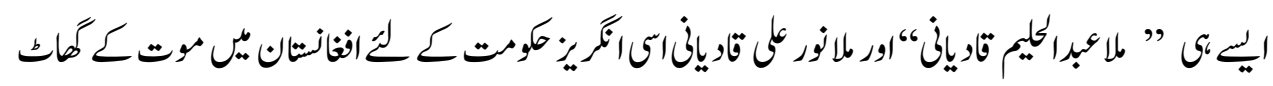




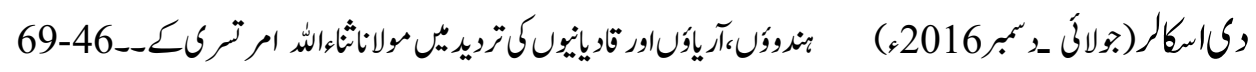

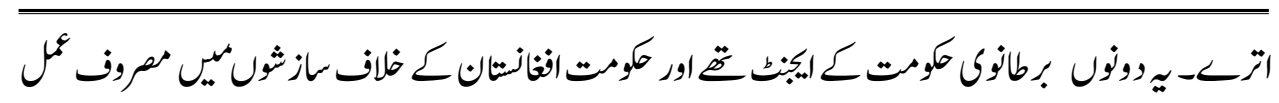

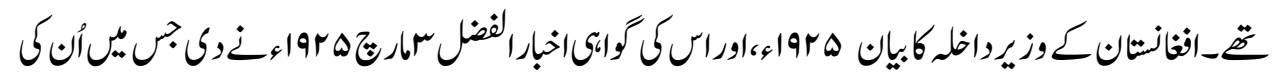

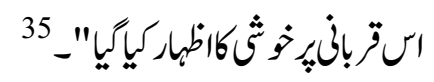

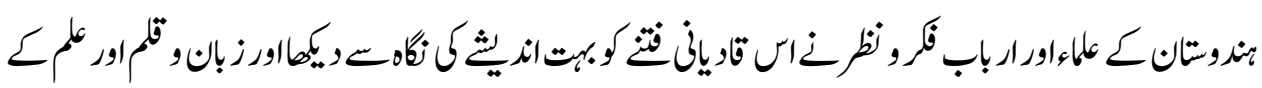

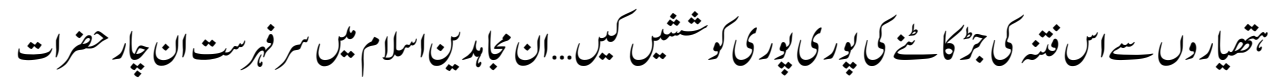

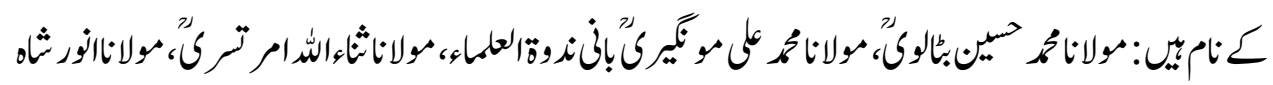

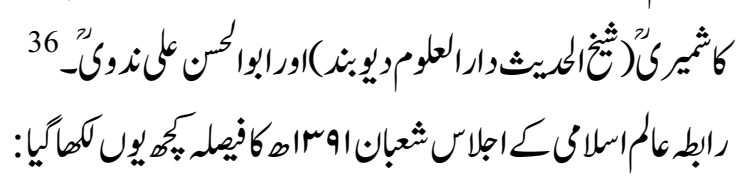

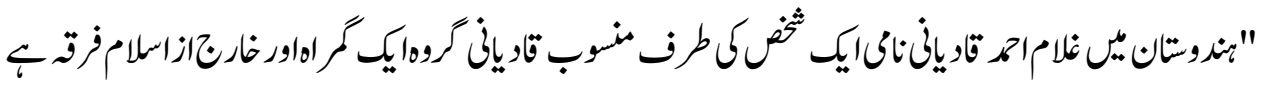

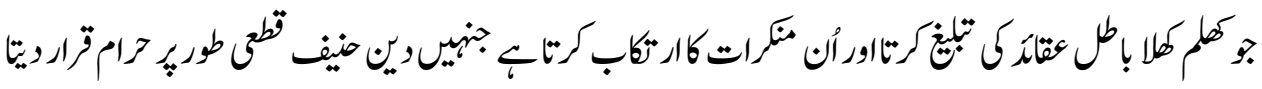
4

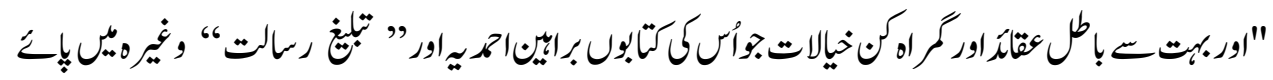

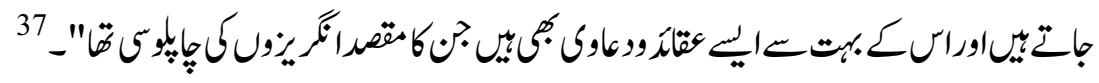

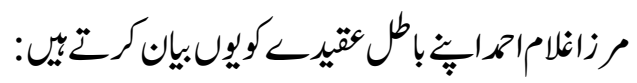

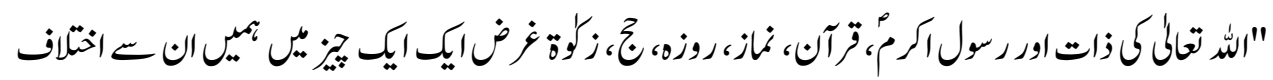

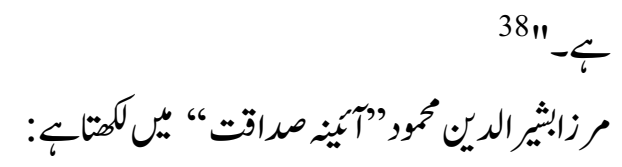

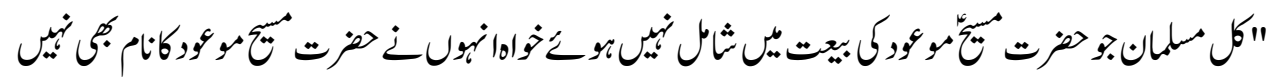

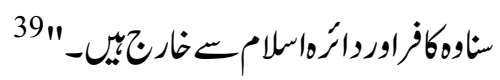

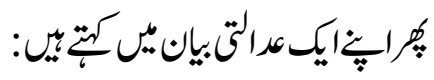

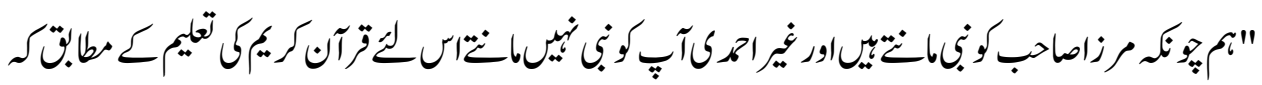

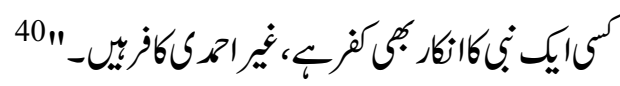

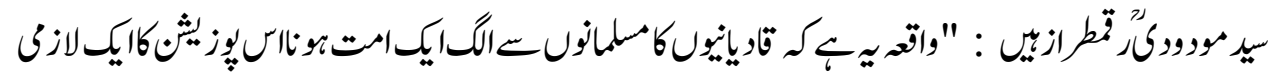

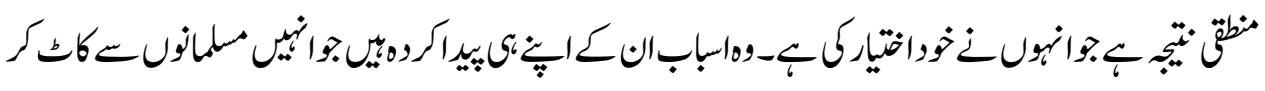




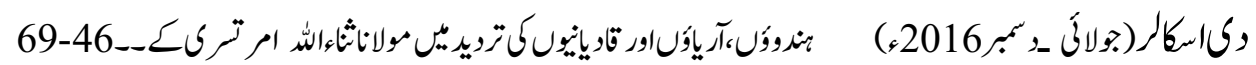

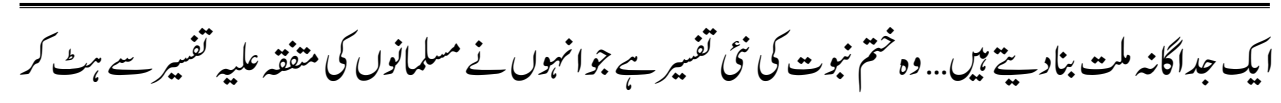

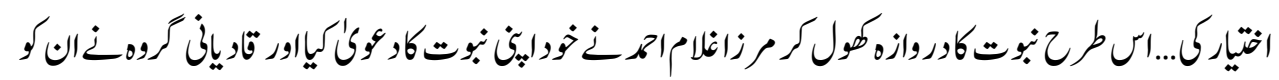

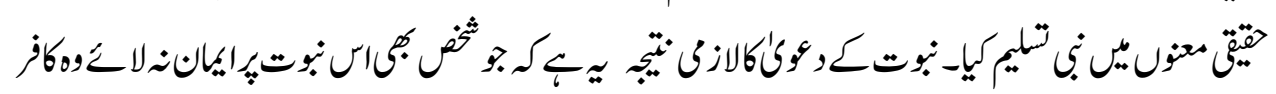

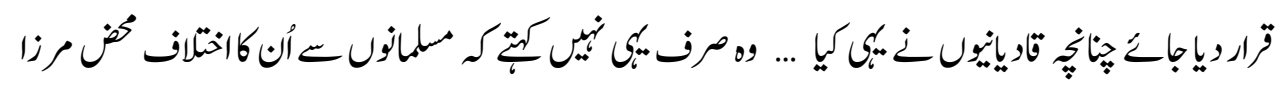

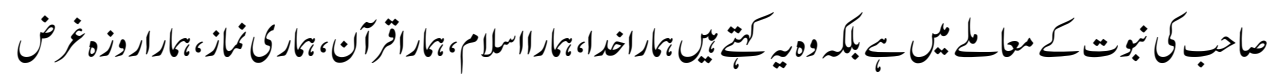

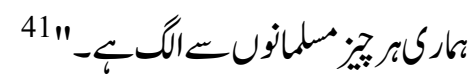

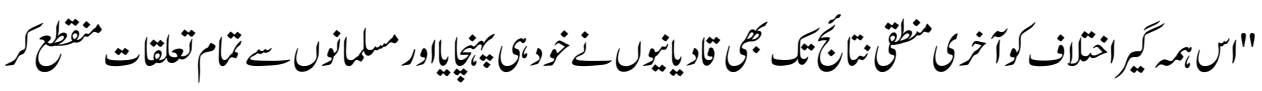

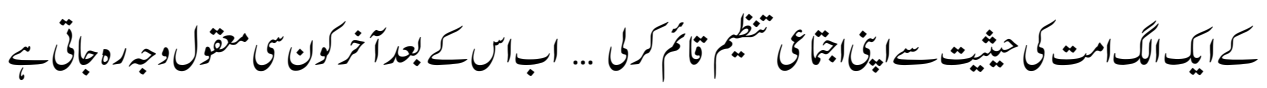

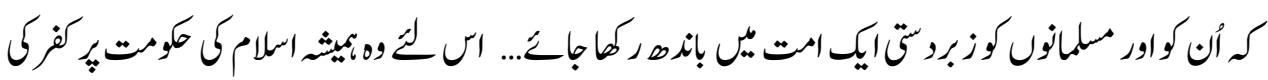

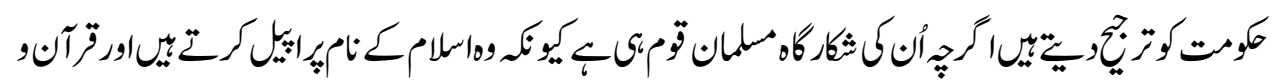

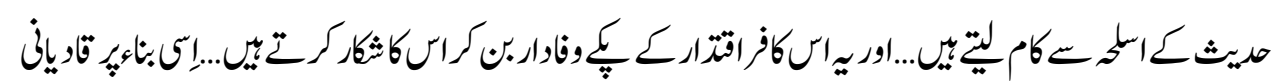

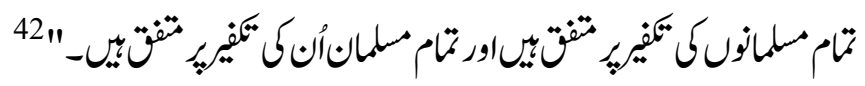

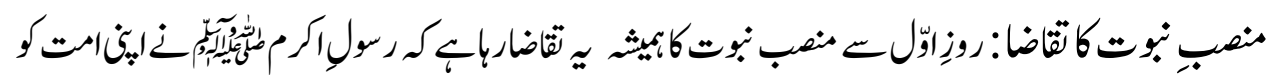

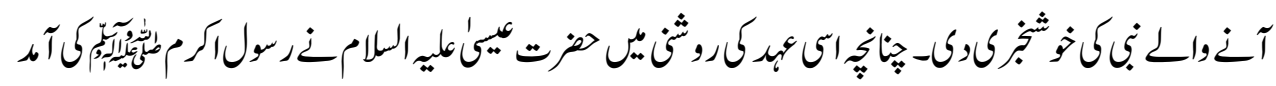

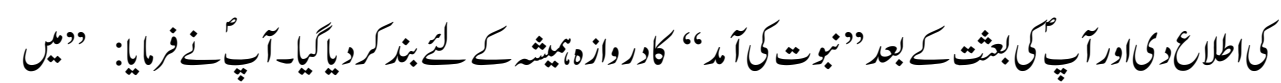

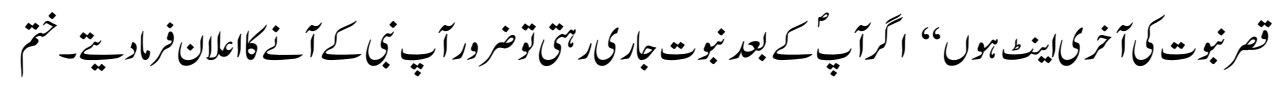

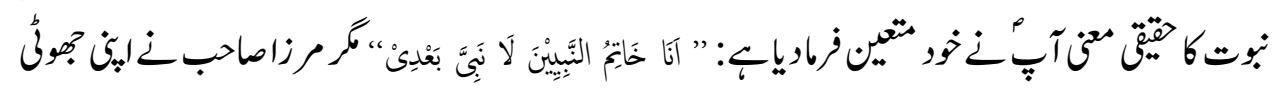

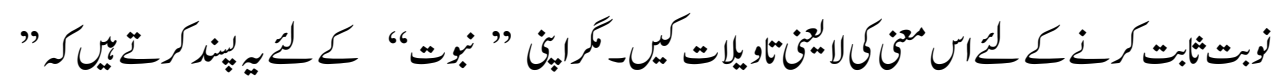

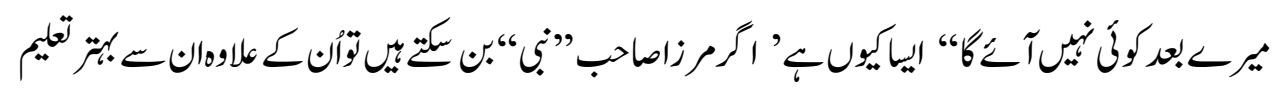

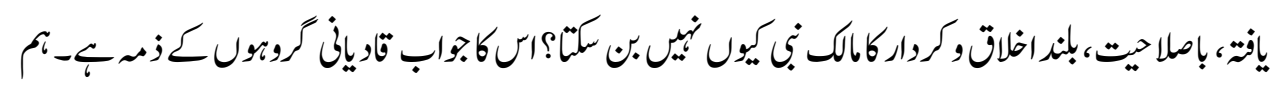

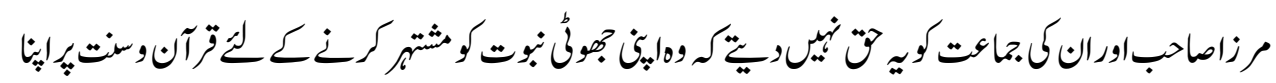

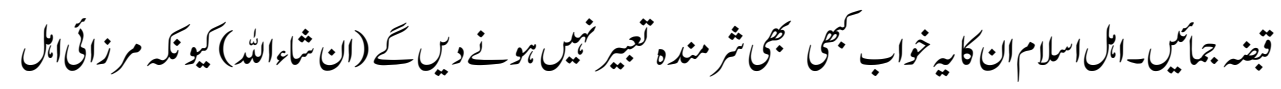

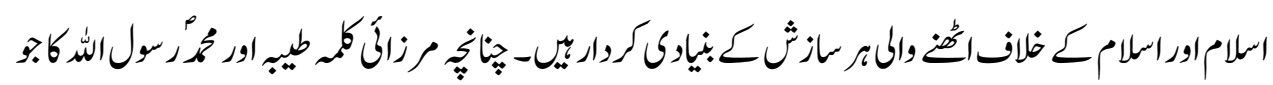

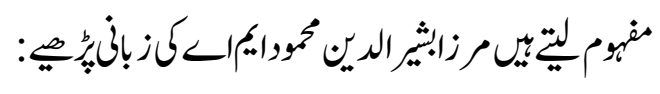




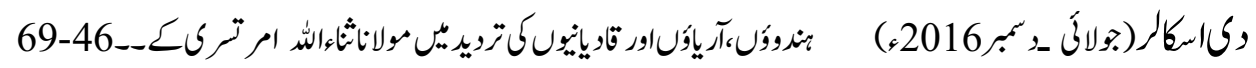

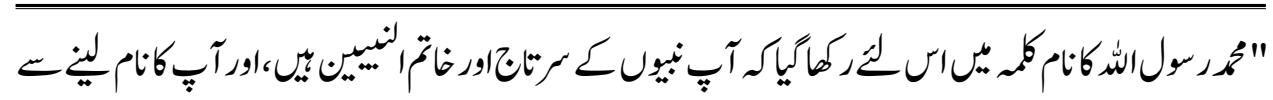

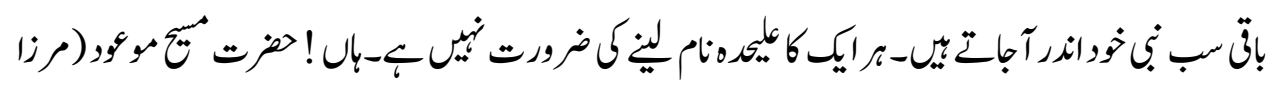

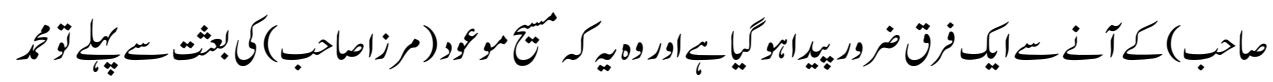



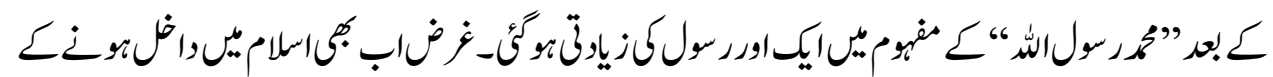

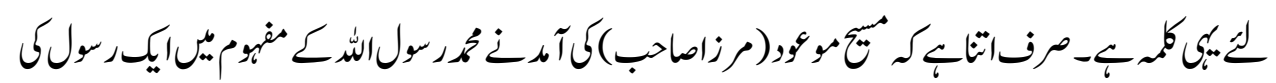

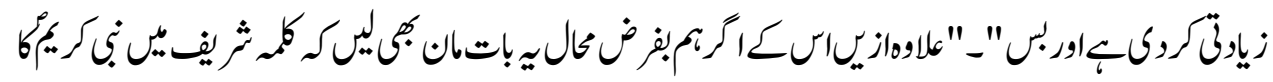

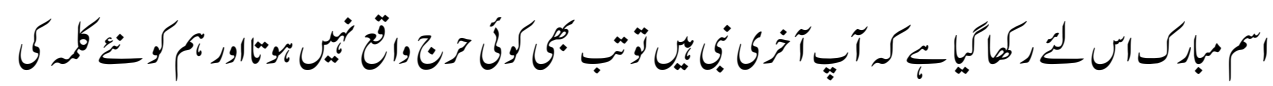

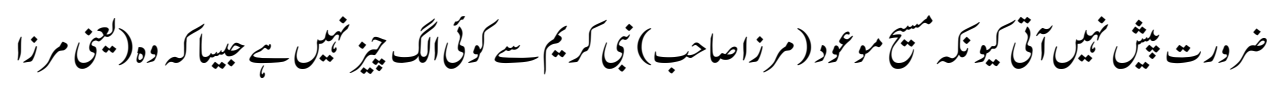

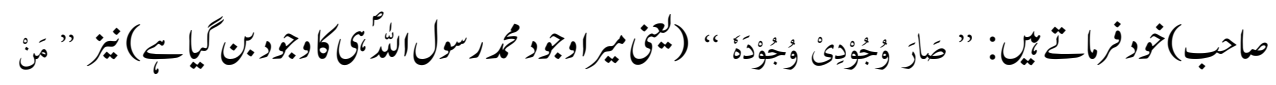

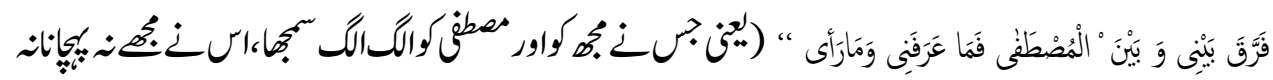

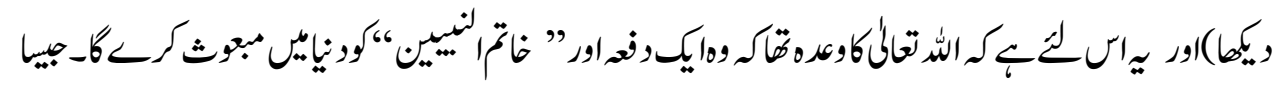

$$
\text { كَ آيت }
$$

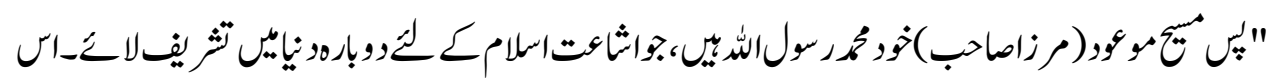



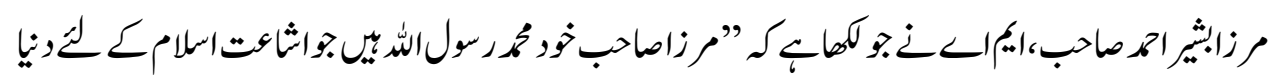

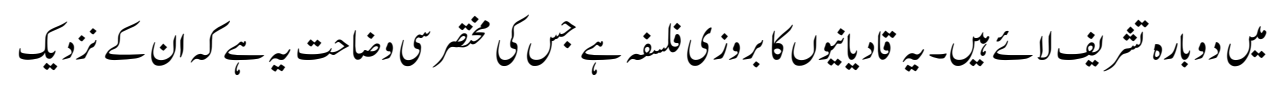

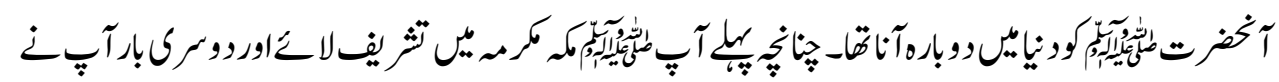

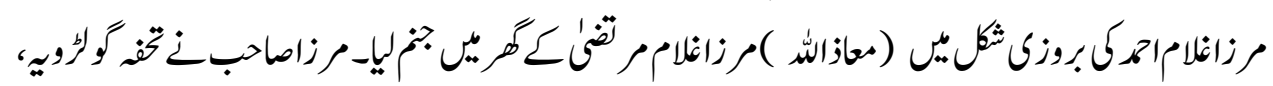

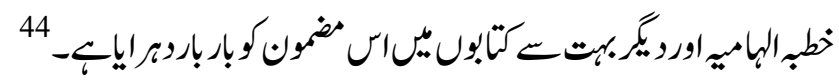

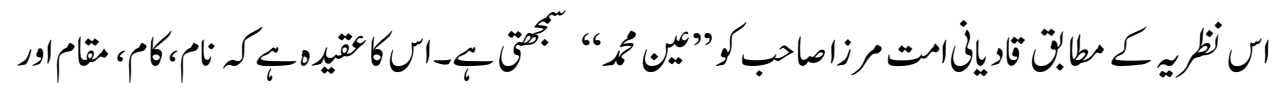

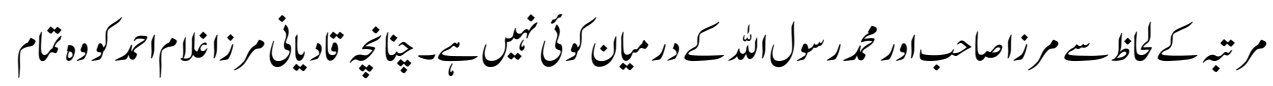

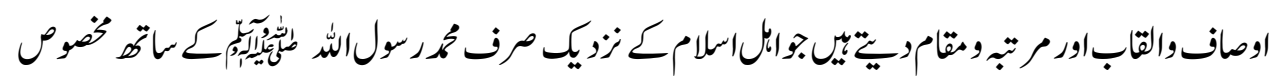




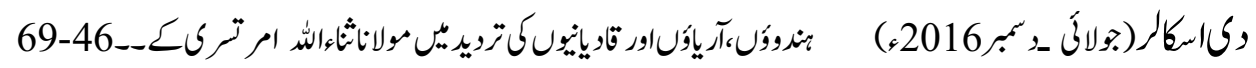

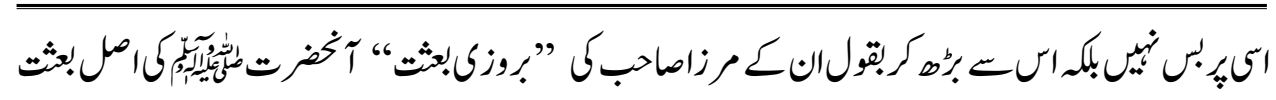

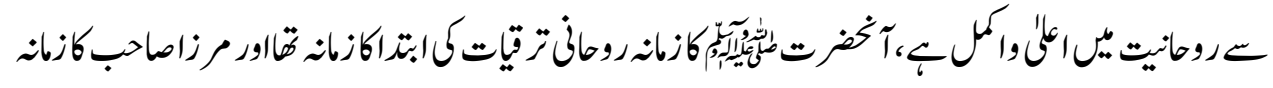

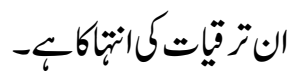

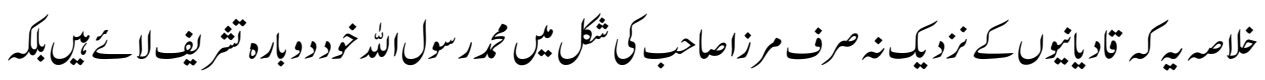

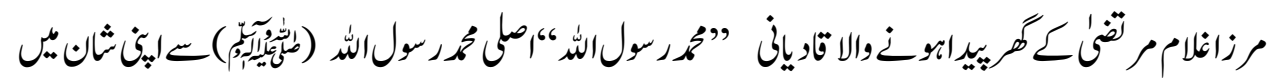
$-4$

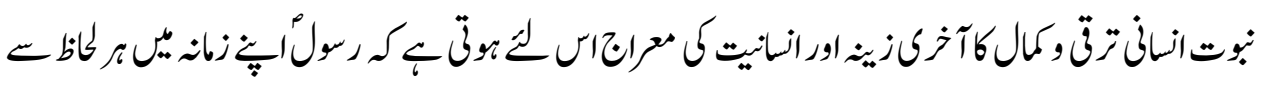

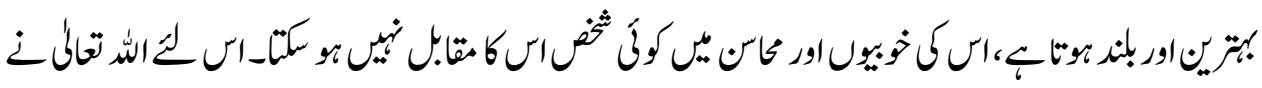

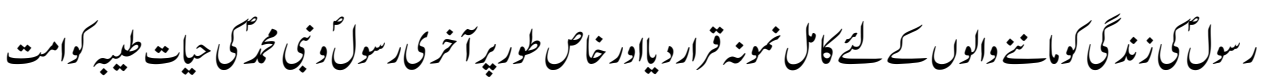

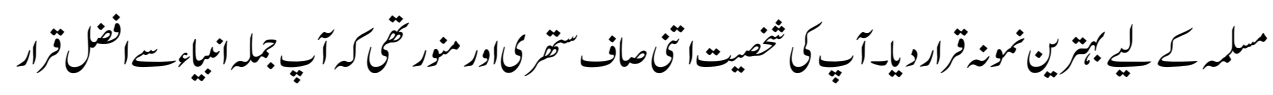
, خلاص .كث:

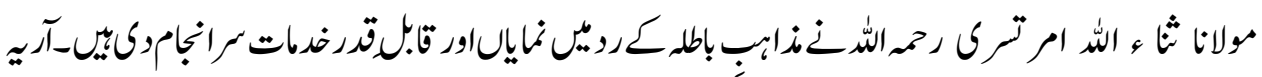

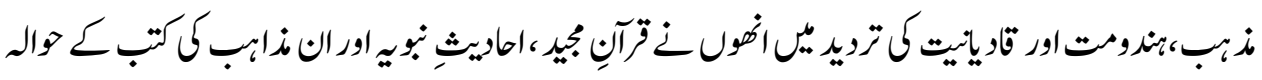

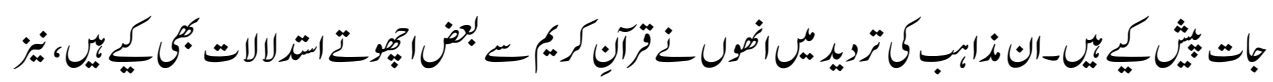

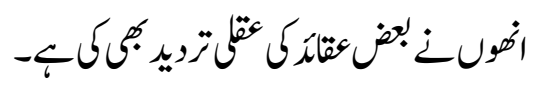

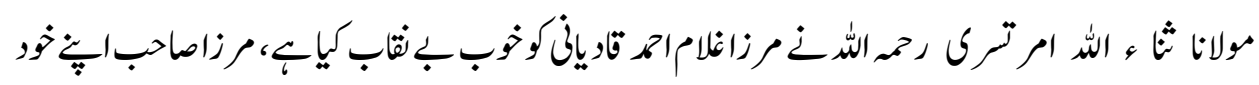

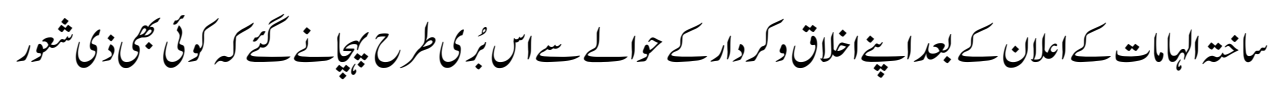

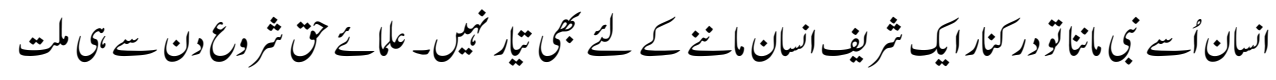

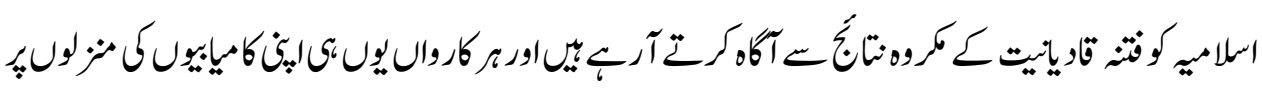

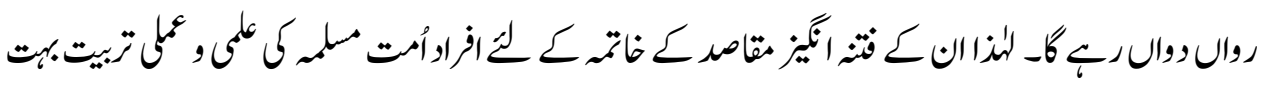

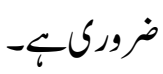

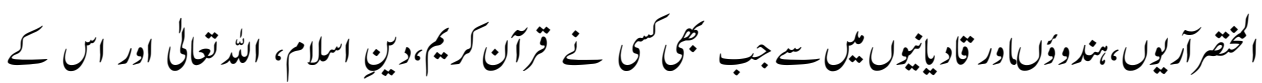

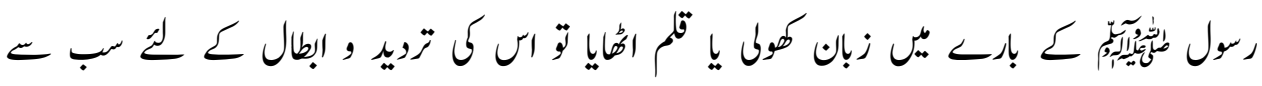




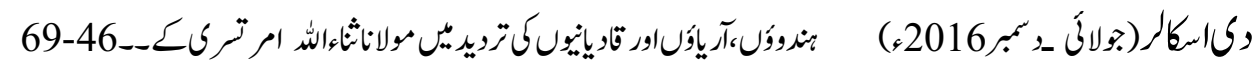

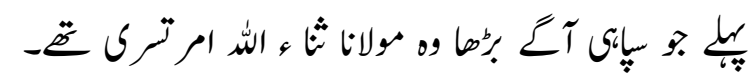

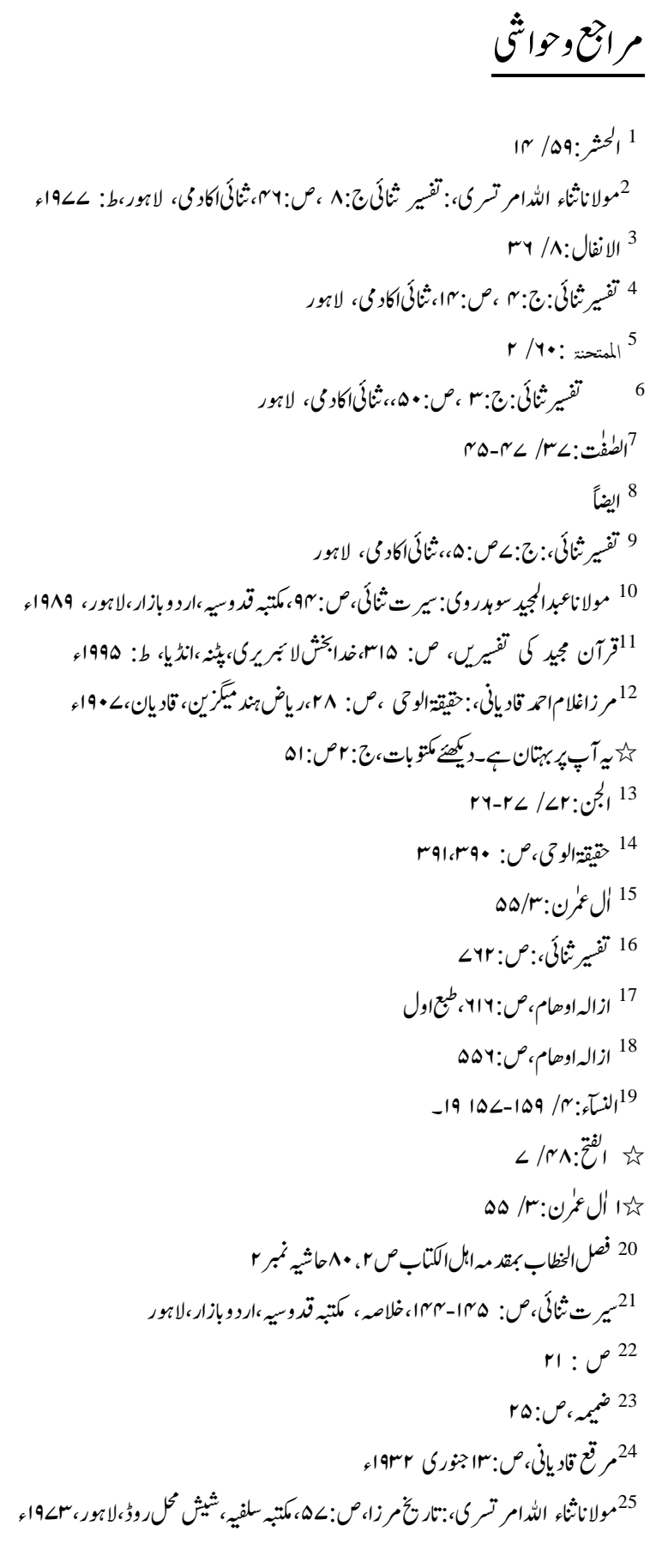




$$
\begin{aligned}
& r: \nu^{26} \\
& 27
\end{aligned}
$$

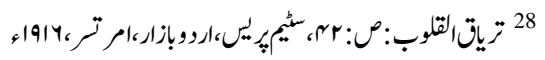

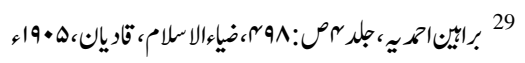

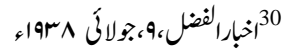

$$
\begin{aligned}
& 31 \\
& 32
\end{aligned}
$$

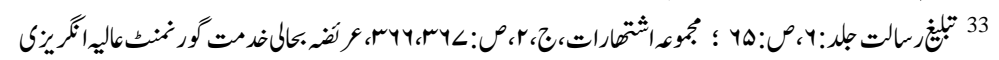

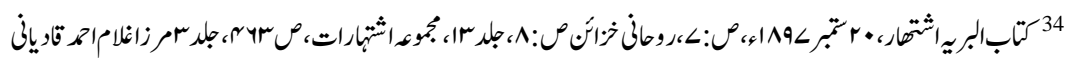

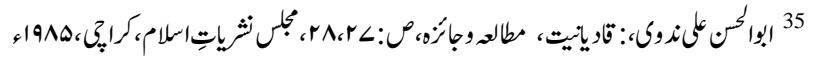

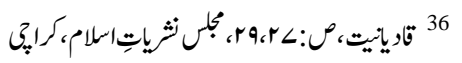

$$
\begin{aligned}
& 37 \text { قاريانيت، ص: } \\
& 38 \\
& \text { ra : } \text { ص }^{39} \\
& \text {, الغضل، } 40
\end{aligned}
$$

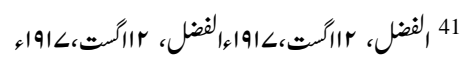

$$
\begin{aligned}
& 42
\end{aligned}
$$

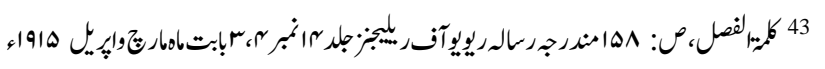

$$
\begin{aligned}
& \text { 11. } 44
\end{aligned}
$$

